\title{
Facies
}

\section{Similarities and differences in the dolomitization history of two coeval Middle Triassic carbonate platforms, Balaton Highland, Hungary

\author{
--Manuscript Draft--
}

Manuscript Number:

Full Title:

Article Type:

Keywords:

Corresponding Author:

FACIES-D-13-00075R1

Similarities and differences in the dolomitization history of two coeval Middle Triassic carbonate platforms, Balaton Highland, Hungary

Original Article

dolomitization, carbonate platform, depositional cycle, pedogenesis, stable isotopes, Middle Triassic, Balaton Highland, Hungary

Janos Haas

HUNGARY

\section{Corresponding Author Secondary}

Information:

Corresponding Author's Institution:

Corresponding Author's Secondary Institution:

First Author:

Janos Haas

First Author Secondary Information:

Order of Authors:

Janos Haas

Tamás Budai, DSc

Orsolya Győri

Sándor Kele, PhD

Order of Authors Secondary Information:

Abstract:

Dolomitization of platform carbonates is commonly the result of multiphase processes.

Documentation of the complex dolomitization history is difficult if completely dolomitized sections are studied. Two Middle Anisian sections representing two coeval carbonate platforms were investigated and compared in the present study. Both sections are made up of metre-scale peritidal-lagoonal cycles with significant pedogenic overprint. One of the sections contains non-dolomitized, partially dolomitized, and completely dolomitized intervals, whereas the other is completely dolomitized. Based on investigations of the partially dolomitized section, penecontemporaneous dolomite formation and/or very early post-depositional dolomitization were identified in various lithofacies types. In shallow subtidal facies porphyrotopic dolomite was found preferentially in microbial micritic fabrics. Microbiallyinduced dolomite precipitation and/or progressive replacement of carbonate sediments could be interpreted for stromatolites. Cryptocrystalline to very finely crystalline dolomite, probably of pedogenic origin, was encountered in palaeosoil horizons. Fabric-destructive dolomite commonly found below these horizons was likely formed via reflux of evaporated sea-water. As a result of the different palaeogeographic settings of the two platforms, their shallow-burial conditions were significantly different. One of the studied sections was located at the basinward platform margin where pervasive fabric-retentive dolomitization took place in a shallow-burial setting, probably via thermal convection. In contrast, in the area of the other, smaller platform shallowwater carbonates were covered by basinal deposits, preventing fluid circulation and accordingly pervasive shallow-burial dolomitization. In the intermediate to deep burial zone recrystallisation of partially dolomitized limestone and occlusion of newly opened fractures and pores by coarsely crystalline dolomite took place.

Response to Reviewers:

For the Editor-in-Chief

We accepted all of the suggested changes of the chief editor with one exception. We used the term "dasycladalean algae" in the text several times following the usage of 
the specialists of the fossil algae that was introduced some years ago. The chief editor corrected this term to the older term "dasycladacean algae", but referring to the recently published special volume of Facies on the fossil algae $(2013,59)$ and within it to the Editorial by Bocur and Fürsich we cannot accept this correction.

We also accepted the suggestion of the chief editor on the incorporation of the result of reactive transport modelling preformed by Whitaker and Jones as to the geothermal convection and the reflux models and we modified the text accordingly.

For Reviewer 1

Line 131 We included a brief description of the features of the succession.

Line 133 We accepted the proposed modification of the sentence

Line 140 Taking into account the note of the chief editor we did not change the term Lines 229-230 We accepted the note and rephrased the sentence, accordingly.

Line 238 Warped crystal faces are typical feature of the saddle dolomite, so we did not modified the text here

Lines 291-293 We accepted the criticism of the reviewer and modification in the composition of the sentence.

Line 360 Considering the reviews for the first version of the manuscript of this paper, we separated the description of the observations from the interpretations. That is why we did not write about root casts in the descriptive part of the paper.

Line 405 The papers mentioned by the reviewer are really important and most of them are relevant to make clear the genesis of the porhyrotopic dolomite. Accordingly we read them and three of them was referred in the revised version of the paper.

Fig. 2 We modified the figure and the caption

Fig. 5 The caption was modified

Fig. 9 It must be a misunderstanding since we used yellow arrows in Fig 8 and their meaning is explained in the caption of this figure.

Fig. 10 We corrected the caption

Fig. 11 We did not change the title of the figure because it shows the paragenetic succession. We modified the figure indicating the place of the formation of the saddle dolomite in the succession.

For Reviewer 2

S1 As far as the microbially-induced dolomitization we modified some part of the discussion but we did not change the essence of our interpretation that it is a very probable option for explanation of early dolomite formation, although another other option is also mentioned in this sentence.

S2 We accepted the suggestion.

S3 We accepted the note of the reviewer and modified the description of the fracture filing cement.

S4 We accepted the note and change the term here and everywhere in the text where we made this mistake.

S5 We omitted the term "nonplanar-a".

S6 We rephrased the sentence.

S7 Considering of the note of the chief editor we did not changed the term.

S9 We specified the place of the observations.

S10 We modified the text to make clear that we returned to our study area.

S 11 We accepted the suggestion of the reviewer.

$\mathrm{S} 12$ We modified the text to make clear that we returned to our study area.

S13, S14 We rephrased these sentences.

S15, S16 Based on the suggestions of the reviewer we rephrased these sentences. 
Similarities and differences in the dolomitization history of two coeval Middle Triassic carbonate platforms, Balaton Highland, Hungary

\author{
János Haas ${ }^{\mathrm{a}}$, Tamás Budai ${ }^{\mathrm{b}}$, Orsolya Győri ${ }^{\mathrm{a}}$, Sándor Kele ${ }^{\mathrm{c}}$, \\ ${ }^{a}$ MTA-ELTE Geological, Geophysical and Space Science Research, H-1117 Budapest, \\ Pázmány P. sétány $1 / \mathrm{c}$ \\ (E-mail: haas@ludens.elte.hu) Tel: 361 3812127, Fax: 3613812128 \\ ${ }^{\mathrm{b}}$ Geological and Geophysical Institute of Hungary, H-1143 Budapest, Stefánia út 14. \\ ${ }^{\mathrm{c}}$ Research Centre for Astronomy and Earth Sciences, Hungarian Academy of Sciences, H- \\ 1112, Budapest Budaörsi út 45
}

\begin{abstract}
Dolomitization of platform carbonates is commonly the result of multiphase processes. Documentation of the complex dolomitization history is difficult if completely dolomitized sections are studied. Two Middle Anisian sections representing two coeval carbonate platforms were investigated and compared in the present study. Both sections are made up of metre-scale peritidal-lagoonal cycles with significant pedogenic overprint. One of the sections contains non-dolomitized, partially dolomitized, and completely dolomitized intervals, whereas the other is completely dolomitized. Based on investigations of the partially dolomitized section, penecontemporaneous dolomite formation and/or very early postdepositional dolomitization were identified in various lithofacies types. In shallow subtidal facies porphyrotopic dolomite was found preferentially in microbial micritic fabrics. Microbially-induced dolomite precipitation and/or progressive replacement of carbonate sediments could be interpreted for stromatolites. Cryptocrystalline to very finely crystalline dolomite, probably of pedogenic origin, was encountered in palaeosoil horizons. Fabricdestructive dolomite commonly found below these horizons was likely formed via reflux of evaporated sea-water. As a result of the different palaeogeographic settings of the two platforms, their shallow-burial conditions were significantly different. One of the studied sections was located at the basinward platform margin where pervasive fabric-retentive dolomitization took place in a shallow-burial setting, probably via thermal convection. In contrast, in the area of the other, smaller platform shallow-water carbonates were covered by basinal deposits, preventing fluid circulation and accordingly pervasive shallow-burial dolomitization. In the intermediate to deep burial zone recrystallisation of partially dolomitized limestone and occlusion of newly opened fractures and pores by coarsely crystalline dolomite took place.
\end{abstract}

Keywords Dolomitization, carbonate platform, depositional cycle, pedogenesis, stable isotopes, Middle Triassic, Balaton Highland, Hungary

\title{
Introduction
}

Petrogenesis of dolomites is commonly the result of multistage processes (e.g. Machel 2004; Nader et al. 2004; Chen et al. 2004; Fu and Quing 2011; Bazargani-Guiliani et al. 2010; Di Cuia et al. 2011). As a result of overprinting of the consecutive dolomitization stages, detection of the paragenetic succession is difficult or cannot be unambiguously achieved in the pervasively dolomitized rocks. However, in some cases there are contemporaneous rock bodies of similar sedimentological characteristics, which show different grades and modes of dolomitization, i.e. non-dolomitized or only partially dolomitized successions and completely 
dolomitized ones occurring relatively close to one another, in the same structural unit. Comparative analysis of these successions provides a good opportunity to understand the complex history of dolomitization. In the Triassic of the Transdanubian Range, Hungary, several examples are known for coeval successions of different dolomitization grades (Haas and Budai 1995; Budai and Haas 1997). One of them is the Middle Anisian Tagyon Formation in the Balaton Highland area that is made up of cyclic peritidal-lagoonal deposits exhibiting characteristic features of pedogenesis and vadose diagenesis in certain horizons. The Tagyon Formation was developed on two neighbouring carbonate platforms. Carbonates of one of these platforms were affected by only partial dolomitization, whereas sedimentologically similar sequences on the other platform were subject to pervasive dolomitization. In this paper the complex petrogenesis of the studied platform carbonates is presented with special regard to the dolomitization processes and the causes of the differences between the two coeval and neighbouring platforms in terms of the grade and mode of dolomitization. The conclusions of this study can be used for genetic interpretation of dolomites formed in similar sedimentary and diagenetic settings.

\section{Geological setting}

The study area is located in the Balaton Highland (SW part of the Transdanubian Range) (Fig. 1), consisting mostly of Triassic formations. The Middle Anisian is made up by coeval platform carbonates and basinal successions (Budai and Vörös 1992; Budai et al. 1999; Vörös et al. 2003). The platform carbonates (Tagyon Formation) were formed on a small, isolated platform (Tagyon Platform) in the central part, and on a larger platform (Szentkirályszabadja Platform) in the north-eastern part of the Balaton Highland. Between the platforms cherty limestone of basinal facies was deposited. The thickness of the basinal succession is the greatest (about $150 \mathrm{~m}$ ) near the tectonically-controlled margin of the Tagyon Platform; from here it gradually decreases north-eastward and it pinches out near the southwestern margin of the Szentkirályszabadja Platform (Fig. 2).

The platform carbonate succession of the Tagyon Formation is made up of cyclic alternations of shallow subtidal and peritidal beds (Budai et al. 1993). In the area of the Tagyon Platform the 50 to $100 \mathrm{~m}$-thick succession is composed of partially dolomitized limestone, whereas in the area of the Szentkirályszabadja Platform the entire formation consists of dolomite (Figs. 1 and 2).

The upper boundary of the Tagyon Formation is a sharp surface, which was interpreted as a drowning unconformity (Budai and Haas 1997; Budai and Vörös 2003a). The platform carbonate succession is overlain by Upper Anisian basinal carbonates with volcanic tuff interbeds (Budai and Haas 1997; Budai et al. 1999; Budai and Vörös 2006). It generally consists of limestone but in the area of the Szentkirályszabadja Platform the succession is completely dolomitized. The Ladinian stage is represented by pelagic limestone in the central part of the Balaton Highland, and platform carbonates in the north-eastern part of the Balaton Highland (Fig. 2). As a result of the subsequent denudation the uppermost Triassic and younger Mesozoic rocks are absent in the studied areas.

\section{Methods}

From the preserved cores of the Dörgicse Drt-1 borehole, 11 samples were taken for detailed petrographic and geochemical studies. Seventeen samples were collected along a section in the Szentkirályszabadja Quarry. We also examined 41 thin-sections which were made in the course of previous investigations. A solution of alizarin red-S and potassium ferricyanide was used to determine the carbonate phases in the samples (Dickson 1966). For 
description of the dolomite texture the classification proposed by Machel (2004) was used; it is a supplemented version of textural classification of Sibley and Gregg (1987).

UV epifluorescence was acquired with a Zeiss Axioskop 40, equipped with Filter Set 09 (Excitation Filter BP 450-490, Beam Splitter FT 510, Emission LP 515) using Hg light illuminator. Cathodoluminescence (CL) studies were undertaken using a MAAS-Nuclide ELM-3 cold-cathode luminoscope.

Stable isotope measurements were performed on micro-drilled powders of calcite and dolomite samples, at the Research Centre for Astronomy and Earth Sciences (Hungarian Academy of Sciences). The analyses were carried out using the continuous flow technique (Rosenbaum and Sheppard 1986; Spötl and Vennemann 2003). ${ }^{13} \mathrm{C} /{ }^{12} \mathrm{C}$ and ${ }^{18} \mathrm{O} /{ }^{16} \mathrm{O}$ ratios were determined in $\mathrm{CO}_{2}$ gases liberated by phosphoric acid using a Finnigan delta plus XP mass spectrometer. Standardization was conducted using laboratory calcite standards calibrated against the NBS 18 and NBS 19 standards. During the measurement of the dolomite samples a laboratory dolomite standard (DST) was used. All samples were measured at least in duplicate and the mean values are in the traditional $\delta$ notation in parts per thousand (\%) relative to Vienna Pee Dee Belemnite (VPDB). Reproducibilities are better than $\pm 0.1 \%$ for $\delta^{13} \mathrm{C}$ and $\pm 0.15 \%$ for $\delta^{18} \mathrm{O}$.

\section{Petrography}

\section{Sedimentary features}

The Tagyon Formation shows a cyclic facies pattern. The cycles are made up of three basic lithofacies types. The most important petrographic characteristics of the types, together with the interpreted depositional environments, are displayed in Fig. 3.

The entire formation is penetrated in core Dörgicse Drt-1 (for location see Figs. 1 and 2) in a thickness of $70 \mathrm{~m}$. The main lithological characteristics of the succession, together with the results of the microfacies analyses and palaeoenvironmental interpretation of the rocks, are presented in Fig. 4. Cyclic alternation of the basic lithofacies types is well recognizable in the lower, non-dolomitized or partially dolomitized part of the succession but less clear in the upper $20 \mathrm{~m}$ of the sequence that was subject to fabric-destructive dolomitization.

A completely dolomitized succession of the upper, $16 \mathrm{~m}$-thick part of the Tagyon Formation is exposed in an abandoned quarry near Szentkirályszabadja (see Figs. 1 and 2). The succession is made up of 0.5 to $2 \mathrm{~m}$-thick finely crystalline dolomite beds commonly capped by 0.1 to $0.3 \mathrm{~m}$-thick pisoidic horizons. A laminated bed occurs in the basal part of the measured section. The usually texture-preserving rock types could be classified into similar lithofacies types to those found in core Drt-1 as far as the sedimentary features are concerned. The logged section with the results of the microfacies investigation is presented in Fig. 5.

\section{Dolomite petrography}

Tagyon Formation in core Drt-1 is mainly composed of limestone, locally with fabricselective dolomite; there are also fabric-destructive dolomite intervals. In the Szk section, exposing the upper part of the Tagyon Formation, the fabric-retentive dolomite is predominant; the fabric-destructive texture is subordinate.

\section{Fabric-selective dolomites}

Different fabric-selective dolomite types were found in the above-defined lithofacies types in core Drt-1. In Lithofacies A the pedogenic nodules, glaebules, and coated grains are mostly composed of dolomicrite although the intragranular micropores (50 to $500 \mu \mathrm{m}$ in size) 
are generally filled by very finely crystalline calcite, and less frequently by dolomite of similar crystal size.

In core Drt-1, a $10 \mathrm{~cm}$-thick interval between 125.3 and $125.4 \mathrm{~m}$ provides a clue to decipher the relationship of the pedogenic texture elements, the cements and the dolomite phases (Figs. 6a, b, c). As is visible in Fig. 6a, light grey limestone progresses into a $5 \mathrm{~cm}$ thick interval containing mm-sized angular to sub-rounded ochre dolomicrite lumps. It is followed by a pisoidic horizon of similar thickness, where the individual coated grains tend to merge upward, and grades into a $1 \mathrm{~cm}$ thick massive dolomicrite layer. The small intergranular pores are filled by finely crystalline inclusion-rich mosaic calcite (Fig. 6b, c). The larger, $\mathrm{mm}$ to $\mathrm{cm}$-sized pores are lined by inclusion-rich non-CL bladed calcite cement (Fig. 6c). The inner part of some of these pores is filled by finely crystalline nonplanar-a dolomite cement with a dull red CL pattern (Fig. 6d). Non-CL, coarsely crystalline limpid mosaic calcite cement commonly appears in the centre of some of the larger pores (Fig. 6c). A fracture with complex filling was encountered in the same sample (Fig 6b) Finely crystalline nonplanar-a dolomite with dull red CL occurs along one wall of the fracture, whereas the other part is occluded by brownish, bladed, inclusion-rich non-CL calcite, growing from both sides of the fracture (Fig 6e).

The micritic fabric elements of Lithofacies C (small peloids with indistinct margins, micritic nodules locally with a filamentous internal structure, cortex of oncoids, and micritic envelope of various grains) are commonly affected by selective dolomitization that is manifested in the appearance of porphyrotopic dolomite (Fig. 7a). This dolomite type may appear in the form of scattered, irregular, 50 to $150 \mu \mathrm{m}$-sized aggregates of microcrystalline dolomite, 15 to $200 \mu \mathrm{m}$-sized individual euhedral, subhedral and anhedral dolomite crystals, or clusters of these kinds of crystal (Figs. 7a and b). The core of the crystals is commonly cloudy, i.e. inclusion-rich. Some crystals contain a brownish growth zone composed of calcite (Fig. 7b). Dull red to orange luminescence characterises this dolomite type (Fig. 7b). The individual crystals or aggregates of porphyrotopic dolomite are usually enveloped by a darkbrownish film (Fig. 7b). Within the micritic nodules the clots are surrounded by very finely crystalline calcite and the 100 to $500 \mu \mathrm{m}$-sized pores are also filled by non-CL calcite of similar crystal size (Fig. 7b). In some cases zoned porphyrotopic dolomite crystals have grown into these small pores (Fig. 7b). Pores, 0.5 to $1.0 \mathrm{~mm}$-sized, occur among the micritic nodules which are occluded by very finely to finely crystalline $(10$ to $20 \mu \mathrm{m})$ mosaic calcite cement (Fig. 7b). There are several $\mathrm{mm}$ to $\mathrm{cm}$-sized vuggy pores, which are lined by inclusion-rich brownish calcite cement. This is characterized by sharp cleavage planes, and a bladed habit with irregular crystal boundaries (Figs. 7c and d). One to $20 \mu \mathrm{m}$-sized dolomite crystals of irregular outline occur randomly in the calcite. The calcite exhibits a zoned CL pattern; the first thin non-CL zone is followed by a mottled one that is covered by thin black and bright subzones (Fig. 7c). Coarsely crystalline (300 to $1000 \mu \mathrm{m})$ limpid mosaic calcite, and/or coarsely crystalline (600 to $800 \mu \mathrm{m})$ dolomite that may exhibit sweeping extinction occurs in the central part of the vugs (Fig. 7e). The mosaic calcite has alternating thin bright orange and thicker black zones under CL (Fig. 7c). The dolomite is dull red, locally with brighter zones. In some cases calcitization of coarsely crystalline dolomite along growth zones or in patches is clearly visible (Fig. 7f).

Some mm-sized vuggy pores are partially or completely filled by dolomicrite. In the former case inclusion-rich bladed calcite, coarsely crystalline dolomite and limpid coarsely crystalline calcite cement types are present above the internal sediment; each cement phase is cut by stylolites (Fig. 7e).

\section{Fabric-retentive dolomites}


In the pervasively dolomitized Szk section the pedogenic fabric of Lithofacies A and the sedimentary and early diagenetic features of Lithofacies B are perfectly preserved. In Lithofacies $\mathrm{C}$ preservation of the sedimentary texture and the early diagenetic cement is commonly also good but in some cases only ghosts of the grains are visible. Complete fabricretentive dolomitization in core Drt-1 was only encountered in samples classified as Lithofacies B.

In the Szk section very finely crystalline dolomite occludes the pores among the pedogenically coated grains or glaebules in Lithofacies A (Figs. 8a, b and c). There are pores of tubular shape which are filled by finely to medium crystalline nonplanar-a mosaic dolomite. The vuggy pores are lined by finely crystalline inclusion-rich dolomite and filled by medium to coarsely crystalline nonplanar-a dolomite (Fig. 8b). Lithofacies B is found in a single peculiar laminated bed-set (see Fig. 4; Bed 2). Peloidal dolomicrite alternates with very finely crystalline dolomite laminae; individual 100 to $500 \mu \mathrm{m}$-sized crystals cross all laminae (Fig. 8d). The dolomicrite is overlain by a thin peloidal wackestone layer that is followed by clotted micrite and then slightly undulating dolomicrite to very finely crystalline and finely crystalline dolomite laminae (Fig. 8e). In Lithofacies C, in very finely to finely crystalline nonplanar-a dolomite matrix, micritic outlines of bioclasts or micritized grains are visible. In some beds moulds after skeletal elements of dasycladaleans are abundant. The moulds are usually partially or completely filled by finely crystalline nonplanar-a dolomite, but empty mouldic pores also occur. In some samples fibrous dolomite cement occurs among the remnants of dasycladalean algae (Fig. 8f, g). The larger pores are filled by finely to medium crystalline nonplanar-a dolomite. Medium to coarse planar-s dolomite cement occurs in the largest vuggy pores. This dolomite cement was commonly affected by calcitization. In many cases, parts of the vuggy pores are empty.

In core Drt-1 a $2.5 \mathrm{~m}$ thick, completely dolomitized bed with excellently preserved fenestral laminated structure was encountered at the basal part of the Tagyon Formation (see Fig. 4). In this bed the micritic nodules, intraclasts and a few bioclasts (dasycladalean algae, foraminifera, gastropods) occur in clotted micrite and very finely crystalline dolomite matrix (Figs. 9a and c). Fenestral pores are common; sheet-cracks with geopetal pore-filling are also present. The matrix is characterised by a dull red CL, whereas the finely crystalline cement in the small fenestral pores exhibits a non-CL external zone that is followed by bright orange zones (Figs. 9a and b). The larger (mm-sized) pores are filled by coarsely crystalline dolomite, locally with sweeping extinction. Geopetal pore-filling with a micritic basal lamina is also common (Fig. 9c). In this case the upper part of the pore is lined by finely crystalline nonplanar-a crystals while medium to coarse crystals with an alternation of dull and brighter CL zones fill the inner part of the pores (Fig. 9d).

\section{Fabric-destructive dolomites}

Several horizons in the Tagyon Formation in core Drt-1 are pervasively dolomitized, mainly in the uppermost $20 \mathrm{~m}$ of the formation (see Fig. 4). In these intervals fabricdestructive dolomite prevails, although ghosts of some grains (e.g. peloids, bioclasts, oncoids) are locally recognisable. This dolomite is typically finely to medium crystalline, exhibiting planar-s texture (Fig. 10a). In some cases the range of crystal size is very limited (10 to 30 $\mu \mathrm{m})$; in other cases it is much greater $(10$ to $150 \mu \mathrm{m})$. The crystals are usually of brownish colour, and cloudy. In several samples patches of coarsely crystalline dolomite are visible within the finely to medium crystalline dolomite (Fig. 10b). The largest crystals usually occur in the central part of these patches and clearly show features of the saddle dolomite (warped crystal faces, undulatory extinction in crossed polarised light) (Figs. 10c and d). 
In the Szk section fabric-destructive texture, i.e. dolomicrite matrix with medium crystalline planar-s dolomite patches was found only in one sample (see Fig. 5; Bed 9b). It has stylolitic contact with fabric-retentive dolomite of Lithofacies A.

\section{Paragenetic succession}

In the partially dolomitized sequence of core Drt-1, the above-described petrographic observations provided a good opportunity to decipher the succession of the diagenetic processes and the dolomite phases (Fig 11). In Lithofacies A, very finely crystalline calcite and dolomite occur in the intragranular micropores of dolomicritic nodules or coated grains (Fig. 6b). The pores among these grains are filled by finely crystalline calcite cement. In Lithofacies B fenestral pores of the laminated beds are also filled by finely crystalline cement (Fig. 12a). In the dolomitized version of these lithofacies types along with the depositional/pedogenic fabric the pore-filling cement was also affected by fabric-retentive dolomitization; accordingly this process may have taken place subsequent to the early diagenetic infilling of the fenestral pores.

In Lithofacies $\mathrm{C}$ porphyrotopic dolomite appears almost exclusively in micritic fabric elements (clotted peloidal micrite, micritic nodules, cortex of oncoids), probably formed via microbial mediation (Figs. 7a and b). There are examples for concentration of porphyrotopic dolomite in certain micrite microlayers of the cortex of oncoids (Fig. 7a). In contrast, this dolomite type is usually missing in finely crystalline calcite occluding the pores between the nodules (Fig. 7b). These petrographic observations suggest initiation of porphyrotopic dolomite genesis penecontemporaneously with the formation of the micritic fabric elements exhibiting clotted or filamentous microstructure. Dissolved surfaces and calcitic growth zones of the porphyrotopic dolomite crystals (Fig. 7b) point to calcitization (dedolomitization), which most probably took place under near-surface diagenetic conditions.

Larger vuggy pores, cross-cutting all of the above-mentioned occasionally, partially or completely dolomitized micritic fabric elements, and very finely to finely crystalline porefilling cements were observed in all lithofacies types discussed above (Figs. 6c and 7d). These vugs are commonly lined by inclusion-rich calcite cement while the inner parts of the pores are typically filled either by medium to coarsely crystalline dolomite or coarsely crystalline mosaic calcite or both (Fig. 6c). This suggests that the formation of vuggy pores postdates precipitation of the finely crystalline cement, and predates precipitation of the inclusion-rich bladed cement. Coarsely crystalline dolomite cement, filling the inner part of some of the vugs, was formed after the bladed calcite (Fig. 7e). Coarsely crystalline dolomite is also present in fractures cross-cutting the inclusion-rich calcite cement.

The replacive fabric-destructive dolomitization probably took place subsequent to the earliest diagenetic phases. There are examples for a very sharp boundary between perfectly fabric-retentive and completely fabric-destructive dolomite types (Fig. 12b). This pattern can be explained either by single-phase early diagenetic dolomitization, which affected layers of significantly different porosity, or by two dolomitization phases; an earlier fabric-retentive phase that was followed by a later destructive one. In either case the fabric-destructive dolomitization is post-dated by the formation of the coarsely crystalline dolomite in pores and fractures (Fig. 12c).

In some cases calcitization (dedolomitization) of the dolomite cement is clearly visible along growth zones and in patches (Fig. 7f). Fractures filled with the coarsely crystalline dolomite cement are cross-cut by fractures filled with coarsely crystalline limpid calcite cement (Fig. 12c). Both this calcite and dedolomite contain Fe-rich growth zones as revealed by staining. The CL pattern of this calcite is characterised by the alternation of black and bright orange zones with a last dull red phase (Fig. 12d). 
In the Szk section in Lithofacies C, the common occurrence of microbial encrustation, of a microboring-derived micrite envelope and micritised grains indicate marine diagenesis as the earliest diagenetic phase. Characteristic features of marine cement are also preserved in some beds in the form of fibrous dolomite pseudomorphs (mimically replaced aragonite cement) among the originally aragonitic skeletal elements, which subsequently dissolved, probably under meteoric conditions. Pedogenic alteration of the previously deposited sediments (development of Lithofacies A) also took place during subaerial exposure episodes. The pervasive replacive dolomitization post-dated all of the above-mentioned pedogenic and early diagenetic processes.

Medium to coarsely crystalline dolomite cement in some larger pores represents the last stage of dolomite formation. It was commonly subject to dedolomitization. Precipitation of coarsely crystalline calcite cement may have also taken place during this phase.

Well-developed stylolites were observed in every lithofacies types all along the studied section. They may penetrate all textural elements, including the medium to coarsely crystalline dolomite cement, but there is no data for their relationship to the fracture-filling calcite cement.

\section{Stable carbon and oxygen isotopes}

The results of the stable isotope analyses are presented in Table I and Fig. 13. In Fig. 13 the $\delta^{13} \mathrm{C}$ and $\delta^{18} \mathrm{O}$ range of calcites precipitated in equilibrium with Anisian seawater is also displayed, according to analysis of well-preserved articulate brachiopod shells (data of Korte et al. 2005). There is a remarkable difference between the $\delta^{18} \mathrm{O}$ values of the two studied sections, whereas the $\delta^{13} \mathrm{C}$ values are similar (Fig. 14).

As far as the section of core Drt-1 is concerned, the $\delta^{13} \mathrm{C}$ values vary in the range from 1.4 to $3.0 \%$. The range of the $\delta^{18} \mathrm{O}$ values is much wider; it is between -7.4 and $-2.9 \%$. Within this range a sample taken from fibrous calcite cement yielded the least depleted value $(-2.9 \%)$, while $-4.4 \%$ was measured in fracture-filling bladed calcite. Samples taken from slightly dolomitized limestone with micritic to very finely crystalline matrix and pore-filling calcite cement are characterised by more negative $\delta^{18} \mathrm{O}$ values $(-5.7$ and $-5.4 \%$ ), which are within the range of the fabric-retentive dolomite samples ( -6.2 to $-3.4 \%$ ). The most depleted $\delta^{18} \mathrm{O}$ values were measured in coarsely crystalline calcite $(-7.2 \%)$ and saddle dolomite cement $(-7.4 \%)$, respectively.

The $\delta^{13} \mathrm{C}$ values vary from 1.1 to $2.9 \%$ in the samples taken from the section of the Szentkirályszabadja Quarry. The range of $\delta^{18} \mathrm{O}$ is between -3.9 and $1.4 \%$. Within this range the highest value $(1.4 \%$ ) was measured in a pedogenic dolomicritic nodule. Values from -1.3 to $-0.2 \%$ were measured in fabric-retentive dolomites representing various lithofacies types. The partially fabric-retentive and completely fabric-destructive samples yielded values between 1.1 and $-2.0 \%$. The dolomitized cements yielded -2.2 to $0.1 \%$ values.

The majority of $\delta^{18} \mathrm{O}$ values of Szentkirályszabadja section fit into the Anisian marine calcite range (Korte et al. 2005), although a few samples (including fabric-retentive and fabric-destructive dolomite and vug-filling cement) provided slightly more positive values (max. 1.4\%). From the samples of this section, the most depleted value $(-3.9 \%$ ) was measured in the medium to coarsely crystalline vug-filling dolomite cement phase.

\section{Interpretation of depositional environments and pedogenic processes}

Based on petrographic characteristics (matrix/grain/cement relations, grain properties, microfabric, etc.) and fossil assemblages, the interpretation of the depositional environments and related post-depositional alternations of the distinguished lithofacies types is summarised below. 
Clotted peloidal micrite is the most ubiquitous texture of Lithofacies $\mathrm{C}$ that implies prevalence of microbially-mediated carbonate production (Chafetz 1986; Riding 2000 and 2002). Since there is no trace of desiccation (desiccation cracks and pores are absent) the deposition may have taken place in a low to medium-energy subtidal depositional environment (Tucker and Wright 1990), i.e. in a more or less protected part of the internal carbonate platform. Peloid aggregates, larger mm-sized micritic nodules, and microbially coated grains (oncoids) may have locally developed in this protected environment. A lightsaturated, shallow $(5$ to $20 \mathrm{~m}$ ) and well-oxygenated sea-bottom describes the habitat of dasycladaleans. Redeposited skeletal fragments of these algae probably occur in the clotted micrite texture and storm or current-controlled redeposition may have led to massive occurrence of sand-sized fragments of dasycladaleans in some horizons. As a result of the activity of endolithic microorganisms (algae, cyanobacteria, fungi) micritic envelopes formed around most of the skeletal grains.

The millimetre-scale lamination that is commonly associated with fenestral fabric in Lithofacies B implies a peritidal (tidal flat) palaeoenvironment (Shinn 1983). Most of the fenestral laminites have an undulating, crinkled appearance. Small-scale domal structures were also found. These features suggest a microbial (cyanobacterial) mat origin of these laminites (Tucker and Wright 1990). This interpretation is also supported by the calcified microbial filaments found in some of the laminites. Desiccation of the previously deposited sediment played a substantial role in the early diagenesis; it led to the formation of desiccation pores, shrinkage cracks, sheet cracks and rip-up clasts in the upper intertidal to supratidal zone (Shinn 1983).

Microfabric characteristics of rocks classified as Lithofacies A (nodules with diffuse margins, desiccation cracks, coated grains, calcified filaments, root casts) clearly indicate their pedogenic origin (Tucker and Wright 1990; Alonso-Zarza and Wright 2010). Most of their features are typical for the beta calcretes (sensu Tucker and Wright 1990) of predominantly biogenic origin. Coated grains prevailing in most pedogenic horizons were formed by multiple processes. The nuclei of these grains may have been formed via desiccation or root activity; it was followed by a coating controlled by biological factors, i.e. roots and microorganisms (Tucker and Wright 1990; Alonso-Zarza et al. 1992; Alonso-Zarza and Wright 2010). Laminated pisolitic crusts were also reported from modern supratidal environments, developed under humid (South Florida) and arid (Arabian Gulf) climatic conditions (Scholle and Kinsman 1974; Shinn 1983). During episodes of subaerial exposure, the previously formed subtidal-peritidal deposits were subjected to meteoric diagenetic processes, which may have resulted in significant alteration of the sedimentary fabric of Lithofacies B and C.

In core Drt-1 regular alternation of Lithofacies A, B and C was observed in the Tagyon Formation (see Fig. 4). Eight cycles, 4 to $6 \mathrm{~m}$ thick, were found in the lower part of the succession. In the upper, 30 m-thick part, only 2 cycles could be recognised. However, due to fabric-destructive dolomitization, recognition of the cycles is rather uncertain in this interval. In the Szk section that represents the upper part of the formation a similar cyclic pattern was recognised, although member B was found only in the basal part of the measured section (see Fig. 5). The basic characteristics of the cycles are akin to those described in the Dachstein-type platform carbonates and defined as Lofer cycles (Fischer 1964; Haas 2004), accordingly the facies interpretation of the cycle members is also similar. Lithofacies $\mathrm{C}$ corresponds to member $\mathrm{C}$ of the Lofer cycles which was interpreted as shallow-subtidal lagoon facies formed in the euphotic zone. Lithofacies B is very similar to Member B representing peritidal (tidal flat) facies. Lithofacies A is akin to Member A of the classic Lofer cycles; both were formed during subaerial exposure via pedogenic processes, although 
due to the different climatic conditions (Haas et al. 2012) there are remarkable differences in the features of the palaeosoil horizons.

\section{Dolomite genesis and diagenetic evolution}

The cyclic succession of the Tagyon Formation was formed in the internal part of isolated carbonate platforms (Fig. 1b) and reflects high-frequency relative sea-level changes. During sea-level highstands the platforms were inundated by a shallow sea. Restricted parts of the bottom of the platform interior may have been covered by microbial mat-producing, penecontemporaneously lithified carbonate deposits of clotted peloidal fabric. Clotted micritic aggregates (microbial nodules), microbially-coated skeletal grains, and oncoids also commonly developed in this environment. Preferential occurrence of porphyrotopic dolomite within micritic sediment of microbial origin suggests microbially-induced dolomite precipitation as the first stage of formation of this dolomite type.

In modern microbial mats various carbonate precipitates (high- $\mathrm{Mg}$ calcite and/or $\mathrm{Ca}$ dolomite, aragonite) may be produced, depending on the biological activities of microorganisms and environmental conditions (Wright 2000; Wright and Wacey 2005; Spadafora et al. 2010). The co-existence of remains of extracellular polymeric substance (EPS) and bacterial bodies, associated with $\mathrm{Ca} / \mathrm{Mg}$ carbonate, implies that organic matter and microbial metabolism play a fundamental role in the precipitation of the peloid-forming minerals (Vasconcelos et al. 2006; Bontognali et al. 2008; Sánchez-Román et al. 2008; Spadafora et al. 2010). Studies on modern organic-rich sediments revealed the importance of microbially-mediated degradation of organic material that results in removal of sulphate in the shallow subsurface, increasing carbonate alkalinity and thereby favourable conditions for dolomite precipitation. Concentration of $\mathrm{Mg}$ in the cyanobacterial sheaths and mucilage that may be liberated in unhydrated form from degraded EPS is another factor that may favour for dolomite formation (Wright 1997; 2000). From Holocene peritidal deposits in Belize, matrixreplacive and selective dolomitization of $\mathrm{Mg}$-calcite foraminifera and micrite was reported (Mazzullo et al. 1987). Genetic link between cyanobacterial degradation and early dolomite formation was pointed out in ancient, silicified microbially dominated carbonates (Wright, 1997). In the course of the shallow subsurface diagenetic evolution, progressive degradation of cyanobacterial mat led to the appearance and increasing abundance of dolomite and ultimately to the formation of a mineralized fabric dominated by rhombohedra (Wright, 1997). Sea-level lowering led to shoaling and establishment of tidal-flat environments on the studied platforms of the Transdanubian Range, beginning in the shallowest parts of the former lagoon. Microbial mat developed on large parts of the tidal flat. In the supratidal zone, desiccation and pedogenic processes led to substantial alteration of the previously deposited sediment.

There are well known examples for the microbial dolomite formation within peritidal microbial mats under hot and dry climatic conditions (Bontognali et al. 2010). Beneath the sabkha surface in Abu Dhabi, the distribution pattern of dolomite suggests post-depositional replacement, which was mostly controlled by the active circulation of near-surface waters (McKenzie et al. 1980; Baltzer et al. 1994). Progressive replacement resulted in good preservation of the sedimentary fabric.

Further sea-level lowering led to subaerial exposure of large parts of the studied platforms, which resulted in erosion, pedogenesis, and meteoric diagenesis. On the subaerially exposed carbonate platforms, under semi-arid climatic conditions that probably prevailed in the studied region (Haas et al. 2012), carbonate crusts and carbonate soils, i.e. calcretes / dolocretes, developed. Most calcretes occur today in regions with mean annual temperature of 16 to $20^{\circ} \mathrm{C}$ (Goudie 1983), but rainfall is the more critical factor; carbonate accumulates in a soil with moisture deficit (Alonso-Zarza and Wright 2010). Pedogenesis could be associated 
with primary dolomite formation, and development of dolocrete horizons (Alonso-Zarza et al. 1998; Wright 2007).

Holocene dolomitized crusts developed on supratidal deposits and heavily penetrated by mangrove roots were reported from Belize, Central America (Mazzullo et al. 1987). The dolomite occurs as a replacement of high-Mg calcite micrite and sand-sized high-Mg calcite grains and as cement. Seasonal alternation of short-term hypersalinity and meteoric influx, which led to dilution of interstitial water, was also pointed out on the supratidal flats. The salinity fluctuation resulted in etching of dolomite crystals and selective leaching of aragonite (Mazzullo et al. 1987).

Deposition of the studied shallow marine successions was interrupted by episodes of subaerial exposure and pedogenesis, when the previously formed subtidal-peritidal deposits were subjected to meteoric diagenetic alteration. In the vadose zone from the surface down to the groundwater table intense dissolution, mostly of the aragonitic components (e.g. dasycladalean algae) took place. Larger ( $\mathrm{mm}$ to $\mathrm{cm}$-sized) dissolution cavities may have formed preferentially along the boundary of the vadose and phreatic zones (Tucker and Wright 1990; Read and Horbury 1993). During the next transgression the mouldic and vuggy pores may have been filled by marine cement. However, this earliest cement may have been dissolved later and the newly-formed pores may have been refilled repeatedly either by marine or meteoric cement in the course of the sea-level controlled transgression-regression cycles. Dissolution and calcitization of porphyrotopic dolomite by meteoric fluids most likely occurred during this stage of the diagenetic evolution.

In the Drt-1 succession the fabric-destructive dolomite intervals are as a rule located just below the pedogenically altered horizons (Lithofacies A). Taking into consideration the dry (probably semi-arid) climatic conditions, reflux of evaporated (mesohaline) sea-water through the previously deposited, semi-consolidated, high-permeability sediment may have been responsible for this type of near-surface stratiform dolomitization (Jones and Xiao 2005).

Accumulation of the Tagyon Formation was followed by a subaerial exposure interval of unknown duration (Budai and Haas 1997; Budai and Vörös 2003a). Thereafter acceleration of tectonic subsidence and contemporaneous sea-level rise resulted in drowning of the platforms in both areas in the Late Anisian (Budai and Haas 1997; Budai and Vörös 2003b). Then the evolution of the two areas diverged. In the area of the former Tagyon Platform the basin conditions were prolonged and the Tagyon Formation was covered by an approximately $100 \mathrm{~m}$-thick pelagic succession by the end of the Ladinian. The area of the Szk section was located in the transitional belt between the Szentkirályszabadja Platform and the Balatonfüred Basin where an approximately $500 \mathrm{~m}$-thick sequence of alternating basin, slope and platform facies were deposited coevally. The different early burial histories of the two platforms may explain their different burial diagenetic and dolomitization pattern that is also reflected in their remarkably different $\delta^{18} \mathrm{O}$ isotope values.

Studies carried out in the area of Great Bahama Bank (Melim et al. 2001) and other Neogene to Quaternary isolated carbonate platforms, which have never been deeply buried (Budd 1997; Jones and Luth 2003; Choquette and Hiatt 2007) revealed the importance of dolomitization processes by marine pore-fluids in the early burial stage. Studies of the active circulation below the Great Bahama Bank (Whitaker and Smart 1993), and results of the reactive transport modelling (Whitaker and Xiao 2010) pointed out that forced geothermal convection of cold normal salinity sea-water through carbonate platforms is a viable mechanism of shallow burial dolomitization. . Inferences of these studies suggest that dolomitization of the Tagyon Formation probably continued in a shallow burial setting. Palaeogeographic setting and $\delta^{18} \mathrm{O}$ values of the Szk section allow the application of the geothermal convection model that may have resulted in replacive dolomitization. Moreover, 
in this area even the precipitation of the last, medium to coarsely crystalline cement phase probably took place under relatively low-temperature conditions. Occlusion of pores prevented later water circulation, in the course of the continuing burial. In contrast, during shallow burial of the Tagyon Formation, the small Tagyon Platform did not exist anymore; the previously-formed platform carbonates became covered by basinal deposits (cherty limestone with volcanic tuff intercalations; see Fig. 2). Consequently, suitable conditions for geothermal convection-driven pervasive, low-temperature dolomitization were not given.

Although the uppermost Triassic and younger Mesozoic rocks are missing in the studied areas, extrapolation of geological data (thickness and extension of the formations, tectonic events, periods of regional uplift and erosion) available for the western part of the Transdanubian Range (Haas and Budai 1999; Vörös and Galácz 1998, Budai et al. 1999; Haas 2012) allows the evaluation of the subsequent burial history. However, due to the obviously inexact extrapolated data, the burial depth values given below can be considered as approximate estimations.

As a result of continuous thermal subsidence of the Tethys margin the Middle Triassic Tagyon Formation reached 1 to $1.2 \mathrm{~km}$ burial depth by the Norian (Haas and Budai 1995). Depleted $\delta^{18} \mathrm{O}$ values, measured on microcrystalline and finely crystalline dolomite and calcite in the Drt-1 section, which suggest relatively elevated temperature, may reflect a resetting during recrystallisation; accordingly these values may characterize the conditions of the last recrystallisation event (Machel 2004).

In connection with the incipient rifting of the later Alpine Tethys, an extensional tectonic regime was established during the Late Norian, when the Tagyon Formation reached the deeper intermediate to deep burial zone (1.8 to $2.2 \mathrm{~km}$; Haas and Budai 1995). The pore spaces and the fractures created in this stage were filled with medium to coarsely crystalline dolomite that yielded the most depleted $\delta^{18} \mathrm{O}$ values and locally exhibits characteristics of saddle dolomite. The appearance of saddle dolomite excludes temperatures lower than 60 to $80^{\circ} \mathrm{C}$ (Spötl and Pitman 1998). The extensional regime was maintained and differential subsidence continued during the Jurassic into the Early Cretaceous interval, when the studied succession reached the deep burial zone $(2.5$ to $3.5 \mathrm{~km})$. Precipitation of coarsely crystalline saddle dolomite in cavities and fractures may have also continued at this stage.

A crucial compressional deformation event occurred in the mid-Cretaceous that resulted in the formation of the large synclinal structure of the Transdanubian Range (Haas 2012). This was followed by uplift and intense erosion during the Turonian to Coniacian interval that resulted in the denudation of the entire Jurassic-Lower Cretaceous succession and even a large part of the Triassic sequence on the limbs of the syncline (Haas 1985; 2012). Consequently, after burial the Tagyon Formation was first raised to a near-surface position at this time. Similar tectonically-controlled uplift, denudation and fracturing occurred in several stages during the Cainozoic. As a result of these processes the Tagyon Formation was affected by karstification that might have resulted in dedolomitization of the last dolomite phase and precipitation of calcite in fractures and cavities.

\section{Conclusions}

Coeval Middle Triassic sections, representing the internal part of two carbonate platforms in the area of the Transdanubian Range, were investigated to determine the mechanism and history of their complex dolomitization, leading to partial dolomitization of one of the platform carbonate successions and pervasive dolomitization of the other.

Cyclic successions were deposited on both platforms, controlled by periodic sea-level oscillation. The unconformity-bounded metre-scale cycles are made up of alternating shallow subtidal, tidal flat and palaeosoil facies. 
Based on studies performed on the partially dolomitized section (core Dörgicse Drt-1) primary dolomite precipitation and very early post-depositional dolomitization are interpreted as the first stage of dolomite genesis. In shallow subtidal facies fabric-selective porphyrotopic dolomite was found in microbial fabric elements (clotted micrite matrix, micritic nodules, microbial crusts, cortex of oncoids) that suggest microbially-mediated dolomite precipitation and/or early diagenetic selective replacement of the microbial Mg-calcite components. Microbially-induced dolomite precipitation and/or progressive replacement of carbonate sediments just beneath the surface of the tidal flat resulted in fabric-retentive dolomitization of some of the stromatolite beds. Dolomite might also have been formed by pedogenic processes; dolomitic calcretes or dolocretes were developed in this way. Meteoric diagenesis during the recurrent subaerial exposure episodes may have locally resulted in partial dissolution and calcitization of the porphyrotopic dolomite.

In the partially dolomitized succession (Drt-1) intervals affected by pervasive fabricdestructive dolomitization were observed under subaerial exposure horizons as a rule. This preferential stratiform dolomitization may have been formed via reflux of evaporated seawater in a near-surface diagenetic setting.

As a result of their dissimilar palaeogeographic settings, the burial history and related diagenetic conditions of the two platforms were different. In the basinward marginal zone of the Szentkirályszabadja Platform pervasive fabric-retentive dolomitization took place in a shallow-burial setting, probably via geothermal convection. In the area of the Tagyon Platform the relatively thin platform carbonate formation was covered by a basinal deposit, preventing any intense circulation and accordingly any pervasive shallow burial dolomitization.

By the Late Norian the Middle Triassic platform carbonates reached the deeper intermediate to deep burial zone. Recrystallisation of partially dolomitized limestone and occlusion of newly-opened fractures and pores by medium to coarsely crystalline dolomite can be attributed to this stage.

The genesis of dolomitic rocks is usually the result of complex, multiple processes. In many cases it is initiated by synsedimentary dolomite formation and/or early diagenetic dolomitization in a near-surface setting, but the subsequent dolomitization stages commonly destroy the traces of the early dolomitization processes. In these cases the comparative study of contemporaneously deposited successions that are completely and partially dolomitized respectively, or the study of transitional intervals between the dolomitized and partially or non-dolomitized rock-bodies may provide a good opportunity for reconstruction of the mechanism and history of dolomitization. This study reveals that even neighbouring and coeval platform carbonates with similar sedimentary features may show remarkably different dolomitization patterns due to their different palaeogeographic setting and burial history.

\section{Acknowledgement}

The authors are indebted to Olga Piros for determination of the dasycladalean algae and to Henry Lieberman (Houston) for the linguistic correction of the paper. The editorial guidance of Maurice E. Tucker, furthermore the detailed comments and suggestions of the reviewers Jay M. Gregg and Paulo Boggiani improved the manuscript considerably.

The present study was supported by the Hungarian National Science Fund (OTKA) grant K 81296 (J. Haas).

\section{References}

Alonso-Zarza AM, Wright VP (2010) Calcretes. In: Alonso-Zarza Am, Tanner LH (eds) Carbonates in Continental Settings, Developments in Sedimentology 61, Elsevier, Amsterdam, Oxford, 225-267 
Alonso-Zarza AM, Wright VP, Calvo JP, Garcia del Cura MA (1992) Soil-landscape and climatic relationships in the Middle Miocene of the Madrid Basin. Sedimentology 39:1735

Alonso-Zarza AM, Sanz ME, Calvo JP, Estévez P (1998) Calcified root cells in Miocene pedogenic carbonates of the Madrid Basin> evidence for the origin of Microcodium b. Sedim Geol 16:81-97

Baltzer F, Kenig F, Boichard R, Plaziat J-C, Purser BH (1994) Organic matter distribution, water circulation and dolomitization beneath the Abu Dhabi Sabkha (United Arab Emirates). In: Purser BH, Tucker ME, Zenger DH (eds) Dolomites, vol 21, IAS Spec Publ 409-427

Bazargani-Guiliani K, Faramarzi M, Tak MAN (2010) Multistage dolomitisation in the Cretaceous carbonates of the east Shahmirzad area, north Semnan, central Alborz, Iran. Carbonates Evaporites 25:177-191

Bontognali TRR, Vasconcelos C, Warthmann RJ, Dupraz Ch, Bernasconi SM, McKenzie JA (2008) Microbes produce nanobacteria-like structures, avoiding cell entombment. Geology, 36:663-666

Bontognali TRR, Vasconcelos C, Warthmann RJ, Bernasconi SM, Dupraz Ch, Strohmenger ChJ, McKenzie JA (2010) Dolomite formation within microbial mats in the coastal sabkha of Abu Dhabi (United Arab Emirates). Sedimentology 57:824-844

Budai T, Vörös A (1992) Middle Triassic history of the Balaton Highland: extensional tectonics and basin evolution. Acta Geol Hung 35:237-250

Budai T, Haas J (1997) Triassic sequence stratigraphy of the Balaton Highland (Hungary). Acta Geol Hung 40:307-335

Budai T, Vörös A (1993) The Middle Triassic events of the Transdanubian Central Range in the frame of the Alpine evolution. Acta Geol Hung 36:3-13

Budai T, Vörös A (2003a) Geological setting. In: Vörös A (ed) The Pelsonian Substage at the Balaton Highland (Middle Triassic, Hungary). vol 55, Geol Hung ser Palaeontol, 9-11

Budai T, Vörös A (2003b) The Pelsonian basin evolution. In: Vörös A (ed) The Pelsonian Substage at the Balaton Highland (Middle Triassic, Hungary). vol 55, Geol Hung ser Palaeontol 45-46

Budai T, Vörös A (2006) Middle Triassic platform and basin evolution of the Southern Bakony Mountains (Transdanubian Range, Hungary). Riv Ital Paleontol Stratigr 112:359-371 Budai T, Lelkes Gy, Piros O (1993) Evolution of Middle Triassic shallow marine carbonates in the Balaton Highland (Hungary). Acta Geol Hung 36:145-165

Budai T, Császár G, Csillag G, Dudko A, Koloszár L, Majoros Gy (1999) Geology of the Balaton Highland. Explanation to the Geological Map of the Balaton Highland, 1:50 000. Occasional Papers of the Geol Institute of Hungary 197:169-257

Budd DA (1997) Cenozoic dolomites of carbonate islands: their attributes and origin. EarthSci Rev 42:1-47

Chafetz HS (1986) Marine peloids: a product of bacterially induced precipitation of calcite. J Sed Petrol 56:812-817

Chen D, Quing H, Yang C (2004) Multistage hydrothermal dolomites in the Middle Devonian (Givetian) carbonates from the Guilin area, South China. Sedimentology 51:1029-1051

Choquette PW, Hiatt EE (2007) Shallow burial dolomite cement: a major component of many ancient sucrosic dolomites. Sedimentology 55:423-460

Di Cuia R, Riva A, Scifoni A, Moretti A, Spötl Ch, Caline B (2011) Dolomite characteristics and diagenetic model of the Calcari Grigi Group (Asiago Plateau, Southern Alps - Italy): an example of multiphase dolomitisation. Sedimentology 58:1347-1369

Dickson JAD (1966) Carbonate identification and genesis as revealed by staining. J Sed Petrol 36:491-505. 
Fischer AG (1964) The Lofer Cyclothems of the Alpine Triassic. Kansas Geol Surv Bull 169:107-149

Fu Q, Quing H (2011) Medium and coarsely crystalline dolomites in the Middle Devonian Ratner Formation, southern Saskatchewan, Canada: origin and pore evolution. Carbonates Evaporites 26:111-125

Goudie AS (1983) Calcrete: In: Goudie AS, Pye K (eds) Chemical Sediments and Geomorphology 91-131

Haas J (1985) Senonian palaeogeographic relations of the Transdanubian Central Range. Annual Rep Hung Geol Surv 1983:95-109

Haas J (2004) Characteristics of peritidal facies and evidences for subaerial exposures in Dachstein-type cyclic platform carbonates in the Transdanubian Range, Hungary. Facies 50:263-286

Haas J, Budai T (1995) Upper Permian - Triassic facies zones in the Transdanubian Range. Riv Ital Paleontol Stratigr 101:249-266

Haas J, Budai T (1999) Triassic sequence stratigraphy of the Transdanubian Range, Hungary. Geol Carpath 50/6:459-475

Haas J (ed) (2012) Geology of Hungary. 244 pp

Haas J, Budai T, Raucsik B (2012) Climatic controls on sedimentary environments in the Triassic of the Transdanubian Range (Western Hungary). Palaeogeogr Palaeoclimatol Palaeoecol 353-355: 31-44

Jones B, Luth RW (2003) Temporal evolution of Tertiary dolostones on Grand Cayman as determined by ${ }^{87} \mathrm{Sr} /{ }^{86} \mathrm{Sr}$. J Sed Res 73:187-205

Jones GD, Xiao Y (2005) Dolomitization, anhydrite cementation, and porosity evolution in a reflux system: Insight from reactive transpost models. AAPG Bulletin 80:577-601

Korte Ch, Kozur H.W, Veizer J (2005) $\delta^{13} \mathrm{C}$ and $\delta^{18} \mathrm{O}$ values of Triassic brachiopods and carbonate rocks as proxies for coeval seawater and palaeotemperature. Palaeogeogr Palaeoclimatol Palaeoecol 226:287-306.

Machel HG (2004) Concepts and models of dolomitization: a critical reappraisal. In: Braithwaite CJR, Rizzi G, Darke G (eds): The Geometry and Petrogenesis of Dolomite Hydrocarbon Reservoirs, vol 235, Geol Soc (London) Spec Publ 7-63

Mazzullo SJ, Reid AM, Gregg JM (1987) Dolomitization of Holocene Mg-calcite supratidal deposits, Ambergis Cay, Belize. Geol Soc Am Bull 89:224-231

McKenzie JA, Hsü KJ, Schneider JF (1980) Movement of subsurface waters under the sabkha, Abu Dhabi, United Arab Emirates and its relation to evaporative dolomite genesis. SEPM Spec Publ 28:11-30

Melim LE, Swart PS, Maliva RG (2001) Meteoric and marine-burial diagenesis in the subsurface of Great Bahama bank. In: Ginsburg RN (ed):Subsurface Geology of a Prograding Carbonate Platform margin, Great Bahama Bank: Results of the Bahamas Drilling Project. SEPM Spec Publ 70:137-161

Nader FH, Swennen R, Ottenburgs R (2003) Karst-meteoric dedolomitization in Jurassic carbonates, Lebanon, Geol Belgica 6:3-23

Nader FH, Swennen R, Ellam R (2004) Reflux stratabound dolostone and hydrothermal volcanism-associated dolostone: a two-stage dolomitisation model (Jurassic, Lebanos). Sedimentology 51:339-360

Read JF, Horbury AD (1993) Eustatic and tectonic controls on porosity evolution beneath the sequence-bounding unconformities and parasequence disconformities on carbonate platforms. In: Horbury AD, Robinson AG (eds) Diagenesis and Basin Development Am Ass Petrol Geol, Studies in Geology36:155-197

Riding R (2000) Microbial carbonates: the geological record of calcified bacterial-algal mats and biofilms. Sedimentology 47:179-214 
Riding R (2002) Biofilm architecture of Phanerozoic cryptic carbonate marine veneers. Geology 30:31-34

Rosenbaum J, Sheppard SMF (1986) An isotopic study of siderites, dolomites and ankerites at high temperatures. Geochim Cosmochim Acta 50:1147-1150

Sánchez-Román M, Vasconcelos C, Schmid Th, Dittrich M, McKenzie JA, Zenobi R, Rivadeneyra MA (2008) Aerobic microbial dolomite at the nanometer scale: implications for the geologic record. Geology 36:879-882

Scholle PA, Kinsman DJJ (1974) Aragonite and high-Mg calcite caliche from the Persian Gulf - a modern analog for the Permian of Texas and New Mexico. J Sed Petrol 44:904-916 Shinn EA (1983) Tidal flat environment. In: Schole PA, Bebout DG, Moore CH (eds) Carbonate Depositional Environments. vol 33, Mem Am Ass Petrol Geol 33:173-210 Sibley DF, Gregg JM (1987) Classification of dolomite rock textures. J Sed Petrol 57:967975

Spadafora A, Perri E, McKenzie JA, Vasconcelos C (2010) Microbial biomineralization processes forming modern Ca:Mg carbonate stromatolites. Sedimentology 57:27-40

Spötl C, Pitman JK (1998) Saddle (baroque dolomite) in carbonates and sandstones: a reappraisal of a burial diagenetic concept IAS Spec Publ 26:437-460

Spötl C, Vennemann TW (2003) Continuous-flow isotope ratio mass spectrometric analysis of carbonate minerals. Rapid Comm in Mass Spectr 17:1004-1006

Tucker ME, Wright VP (Eds) (1990) Carbonate Sedimentology, 482 pp

Vasconcelos C, Warthmann R, McKenzie JA, Vissher PT, Bittermann AG, van Lith Y (2006) Lithifying microbial mats in Lagoa Vermelha, Brazil: modern Precambrian relics? Sed Geol 185:175-183

Vörös A, Galácz A (1998) Jurassic palaeogeography of the Transdanubian Central Range. Riv Ital Paleontol Stratigr 104:69-83

Vörös A, Budai T, Kovács S, Piros O, Szabó I (2003) Stratigraphy. In: Vörös A. (ed) The Pelsonian Substage at the Balaton Highland (Middle Triassic, Hungary Geol Hung ser Palaeontol, 55:45-46

Whitaker FF, Smart PL (1993) Circulation of saline groundwaters in carbonate platforms: a review and case study from the Bahamas. In: Horbury AD, Robinson AG (eds) Diagenesis and Basin Development Am Ass Petrol Geol, Studies in Geology 36:113-132

Whitaker FF, Xiao Y (2010) Reactive transport modeling of early burial dolomitization of carbonate platforms by geothermal convection. AAPG Bulletin 94:889-917

Wright VP (2007) Calcrete. In: Nash DJ, McLaren SJ (eds) Geochemical Sediments and Landscapes, 10-47

Wright DT (1997) An organogenic origin for widespread dolomite in the Cambrian Eilean Dubh Formation, Northwestern Scotland. J Sed Res, 67:54-64

Wright DT (2000) Benthic microbial communities and dolomite formation in marine and lacustrine environments - a new dolomite model. In: Glen CR, Prévôt-Lucas L, Lucas J (eds) Marine Authigenesis: From Global to Microbial. SEPM Spec Publ 66: 7-20

Wright D, Wacey D (2005) Precipitation of dolomite using sulphate-reducing bacteria from the Coorong Region, south Australia: siginificance and implications. Sedimentology 52:9871008 


\section{Figure captions}

Fig. 1 a Position of the studied area in the Transdanubian Range (TR). Abbreviations: A: Austria, SK: Slovakia, U: Ukraine, RO: Romania, SRB: Serbia, CR: Croatia, SLO: Slovenia. b Distribution of the coeval Middle Anisian facies on the Balaton Highland (after Budai and Vörös 2006). D: Dörgicse Drt-1 borehole; Sz: Szentkirályszabadja Quarry

Fig. 2 Geological profile between the central and the north-eastern part of the Balaton Highland showing the relationship of the Middle Triassic formations (after Budai and Vörös 2006, modified). Log of core Drt-1 is presented on Fig. 4, geological section of Szentkirályszabadja Quarry (Szk) is shown on Fig 5.

Fig. 3 Petrographic properties and interpreted depositional environment of the basic lithofacies types defined in the studied sections of the Tagyon Formation. Scale bar is $1 \mathrm{~mm}$. Fig. 4 Lithological and microfacies characteristics and facies interpretation of core Dörgicse-1 (Drt-1). Abbreviations: s - samples taken for detailed investigation; $\mathrm{c}$ - cycle boundaries; if lithofacies types; cr/dr - calcrete/dolocrete; ps - pisoidic; o - other; str - stromatolite; br brecciated; st - non-brecciated; $\mathrm{p}$ - peloidal; on - oncoidal; da - rich in dasycladalean algae; pd - porphyrotopic dolomite; cd - coarsely crystalline dolomite; sd - saddle dolomite; fd fabric-destructive; cc - calcite cement; sp - supratidal; in - intertidal; su - subtidal

Fig. 5 Lithological and microfacies characteristics and facies interpretation of the section of the upper part of the Tagyon Formation measured in the Szentkirályszabadja Quarry (Szk). Abbreviations: $\mathrm{s}$ - samples taken for detailed investigation; ; $\mathrm{c}$ - cycle boundaries; If lithofacies types; $\mathrm{pa}$ - pedogenic alteration; $\mathrm{cr} / \mathrm{dr}$ - calcrete/dolocrete; $\mathrm{ps}$ - pisoidic; o - other; str - stromatolite; br - brecciated; st - non-brecciated; $\mathrm{p}$ - peloidal; on - oncoidal; bc bioclastic; pd - porphyrotopic dolomite; cd - coarsely crystalline dolomite; sd - saddle dolomite; fd - fabric-destructive; cc - calcite cement; sp - supratidal; in - intertidal; su subtidal

Fig. 6 Fabric-selective dolomite in Lithofacies A in core Drt-1. (Scale bar is $1 \mathrm{~mm}$ ) a Pedogenic calcrete/dolocrete profile. A/ host rock-transitional horizon; slightly altered dolomitic limestone with irregular light yellow patches and scattered cement-filled pores; B/ nodular horizon with angular to sub-rounded, mm-sized ochre dolomicrite nodules and scarcely coated grains showing normal grading; C/ coated grain horizon; made up of mmsized dolomitized coated grains showing upward-fining trend. The horizontally interlocking planar pores are filled by calcite and dolomite cement. The grains tend to merge upward forming irregular patches; D/ structureless, massive dolomicrite layer; 125.3-125.4 m. b Details of the $\mathrm{C}$ horizon. Irregular pores among the grains are filled by very fine mosaic calcite cement (vfc, arrows). Very finely crystalline dolomite (vfd, arrows) appears as fracture filling that is cut by a younger fissure occluded by bladed calcite (bc, arrows) rich in inclusions along the fracture wall. Stained thin-section; $125.3 \mathrm{~m}$. c Small and larger pores occur among the dolomicrite glaebules and coated grains. The small intergranular pores are filled by finely crystalline mosaic calcite cement. The larger pore in the centre of the picture is lined by medium crystalline bladed calcite (bc). Within this lining finely to medium crystalline dolomite (fd) fills a part of the pore (right side) while mostly coarsely crystalline limpid mosaic calcite cement (cc) fills the remaining space (left side). d CL image of a part of the $\mathrm{C}$ horizon (the area is displayed on Fig. $7 \mathrm{~b}$ and c) The dolomicrite and finely crystalline dolomite (fd) components exhibit dull red luminescence, the finely crystalline calcite and bladed calcite cement (bc) are non-luminescent. e CL image of a part of the C horizon (the area is displayed in Fig. 7b). The dolomicrite grains and the fracture filling finely crystalline dolomite (fd) show dull red luminescence; the finely crystalline pore filling calcite cement (fc) and the bladed fracture filling calcite (bc) are non-luminescent. 
Fig. 7 Fabric-selective dolomite in Lithofacies $\mathrm{C}$ in core Drt-1, scale bar is $500 \mu \mathrm{m}$. a Microbial nodule. The tiny dolomite patches (arrows) are particularly abundant in certain micritic layers of the microbial crust, i.e. their distribution seems to follow the microbial structures. Stained thin-section; $101.0 \mathrm{~m}$. b Micritic lump with clusters of euhedral to anhedral dolomite (pd); left: stained thin-section; the porphyrotopic dolomite exhibits dull red to orange luminescence; right: CL image; $112.6 \mathrm{~m}$. c Vug pore lined by brownish bladed calcite cement (bc) and filled by coarsely crystalline mosaic calcite (cc) in the central part of the pore; left. The inclusion-rich calcite (cb) is black under CL with some dull mottles, while the coarsely crystalline calcite cement has alternating thin bright orange and thicker black zones; right; $112.6 \mathrm{~m}$. d Clotted micritic-very finely crystalline calcite fabric with a gastropod fragment. Porphyrotopic dolomite (pd) occurs in micrite aggregates. There are small pores with finely crystalline calcite cement filling (fc). A larger vug is lined by brownish bladed calcite (bc) and filled by coarsely crystalline mosaic calcite cement (cc); $142.5 \mathrm{~m}$ e Medium to coarsely crystalline dolomite cement (cd) in the inside of a dissolution cavity. The lower part of the cavity is filled by dolomicrite internal sediment (md); in its upper part medium to coarsely crystalline mosaic calcite cement (cc) occurs. A stylolite separates this cement-type from bladed calcite cement (bc). Stained thin-section. $101.0 \mathrm{~m}$. f Vug in limestone; it is lined by acicular calcite (ac, arrow). Saddle dolomite cement (cd) occludes the internal part of the pore. Certain zones of the coarse dolomite crystals transformed to calcite (arrows). Stained thin-section. $115.0 \mathrm{~m}$.

Fig. 8 Fabric-retentive dolomite in Lithofacies $\mathrm{A}, \mathrm{B}$ and $\mathrm{C}$ in the section of the Szentkirályszabadja Quarry (Szk). (Scale bar is $1 \mathrm{~mm}$ ) a Pisolite horizon with light yellow large reworked palaeosoil clasts. There are $\mathrm{cm}$-sized pores (arrows) lined by multiple generation of isopachous dolomite cement. Bed 7c. b Nodules with root casts (nd), and grain aggregates (ag) act as the nuclei of coated grains. Micrite meniscus cement (arrows) occurs at the grain contacts; the inner part of the intergranular pores is occluded by finely to medium crystalline dolomite. Stained thin-section; Sample 7c. c Coated grains; intraclasts act as their nuclei. Stained thin-section. Sample taken from the logged section d Slightly undulating laminated fabric, made up of alternation of dolomicrite and very finely crystalline dolomite laminae. Recrystallisation sub-perpendicular to the lamination (arrows) is visible in some lamina sets. Stained thin-section; Bed 2a. e From the bottom to the top: peloidal grainstone (pg); uneven erosional surface (e, arrow), the depressions are filled by micrite (m, arrow); a laminated microlayer composed of micrite and very finely crystalline dolomite laminae $(\mathrm{lm})$; laminated microlayer made up of clotted micrite and very finely crystalline dolomite laminae (cl). Stained thin-section; Bed 2b. f Remnants of dasycladalean algae fragments. Micrite envelope (arrow) preserved the outlines of the bioclasts. The moulds are filled by finely crystalline dolomite (fd). Very finely crystalline dolomite (vfd) fills the internal hollow of the algae. Dolomitized fibrous cement (yellow arrows) occurs among the bioclasts and micritised grains. Szentkirályszabadja Quarry; from the logged section. g Bioclastic wackestone with dasycladalean alga (Teutloporella peniculiformis). Fenestral pores and intraclasts (soil clasts) are common (pedogenic alteration). Stained thin-section; Bed 4a

Fig. 9 Fabric retentive dolomite of Lithofacies B in core Drt-1. Scale bar is $500 \mu \mathrm{m}$ on the pictures. a Dolomitized clotted micrite fabric. The fenestral pores are filled by very finely crystalline dolomite internal sediment (vfd) and finely crystalline dolomite (fd) Stained thinsection. b CL image of a: the matrix shows dull red luminescence, the pore-filling dolomite exhibits a non-luminescent external zone that is followed by bright orange zones; $144.0 \mathrm{~m}$. c Larger bedding-parallel pore with finely crystalline dolomite internal sediment (vfd). The upper part of the pore is lined by finely crystalline dolomite (fd) while its internal part is occluded by medium to coarse crystals (cd); stained thin-section; d CL image of c: the matrix shows dull red luminescence, the finely crystalline external zone of the pore-filling dolomite 
831 is black and the coarse crystalline dolomite in the internal part exhibits alternation of dull red 832 and brighter orange zones; $144.0 \mathrm{~m}$

833 Fig. 10 Fabric-destructive dolomite in core Drt-1. Scale bar is $500 \mu \mathrm{m}$ on the pictures; a 834 Finely to medium crystalline planar-e-planar-s dolomite. Stained thin-section; $75.8 \mathrm{~m}$. b 835 Coarsely crystalline planar-s dolomite in medium crystalline nonplanar-a and planar-s 836 dolomite. $84.9 \mathrm{~m}$. c and $\mathbf{d}$ Saddle dolomite grown onto the wall of a cm-sized open cavity; c 837 parallel polars; $\mathrm{d}$ - crossed polars, $83.4 \mathrm{~m}$

838 Fig. 11 Paragenetic sequence of the Tagyon Formation in the succession of core Dörgicse 839 Drt-1

840 Fig. 12 (Scale bar is $500 \mu \mathrm{m}$ ) a Micrite with irregular darker patches, and 100 to $2000 \mu \mathrm{m}$ 841 sized fenestrae. A cm-sized planar-shaped dissolution cavity is visible in the centre of the 842 picture. It is lined by fibrous cement; above it laminated micritic internal sediment (is) occurs 843 in the lower part and mosaic cement is present in upper part of the cavity. Similar geopetal fill 844 occurs in some of the smaller pores. The vugs are cut by desiccation cracks (cr), which are 845 filled by fine-grained sediment and/or finely crystalline calcite cement. $115.4 \mathrm{~m}$. b Dolomite of well-preserved peloidal microbial fabric is visible below, fabric-destructive fine to medium crystalline nonplanar-a and planar-s dolomite occurs above it; Note the sharp contact between the fabric-retentive and the fabric-destructive dolomites (arrow). $89.2 \mathrm{~m}$ c Partially dolomitized limestone, cut by a fracture with medium crystalline dolomite infilling. A younger fissure filled by coarsely crystalline calcite cross-cuts the previous one. $77 \mathrm{~m}$. d Saddle dolomite (dc) and coarsely crystalline calcite vug-filling cement in limestone. Note the fine CL zonation of the calcite (non CL - non CL zone with thin bright orange bands - dull red 853 CL with thicker zones). $82.2 \mathrm{~m}$

854 Fig. 13 Relationship between $\delta^{18} \mathrm{O}$ (V-PDB) and $\delta^{13} \mathrm{C}$ (V-PDB) values measured in the samples of core Dörgicse-1 (Drt-1) and Szentkirályszabadja (Szk) section

Table I $\delta^{18} \mathrm{O}(\mathrm{V}-\mathrm{PDB})$ and $\delta^{13} \mathrm{C}(\mathrm{V}-\mathrm{PDB})$ values measured in the samples of core Dörgicse-1 


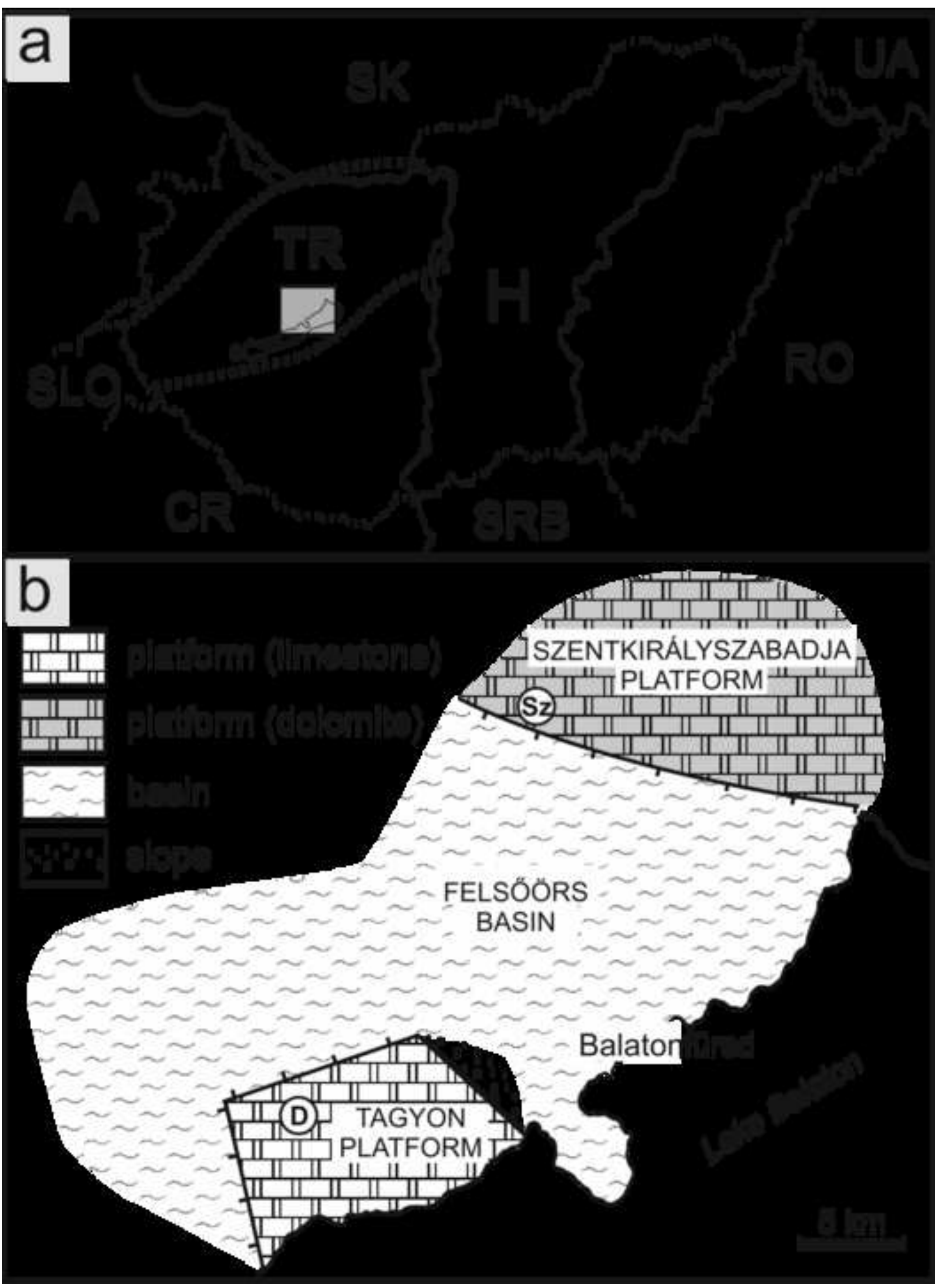


B a l a $\mathrm{t}$ o $\mathrm{n} \mathrm{H}$ i g h l a $\mathrm{nd}$

Drt-1

\section{Veszprém Plateau}

\section{Szk}

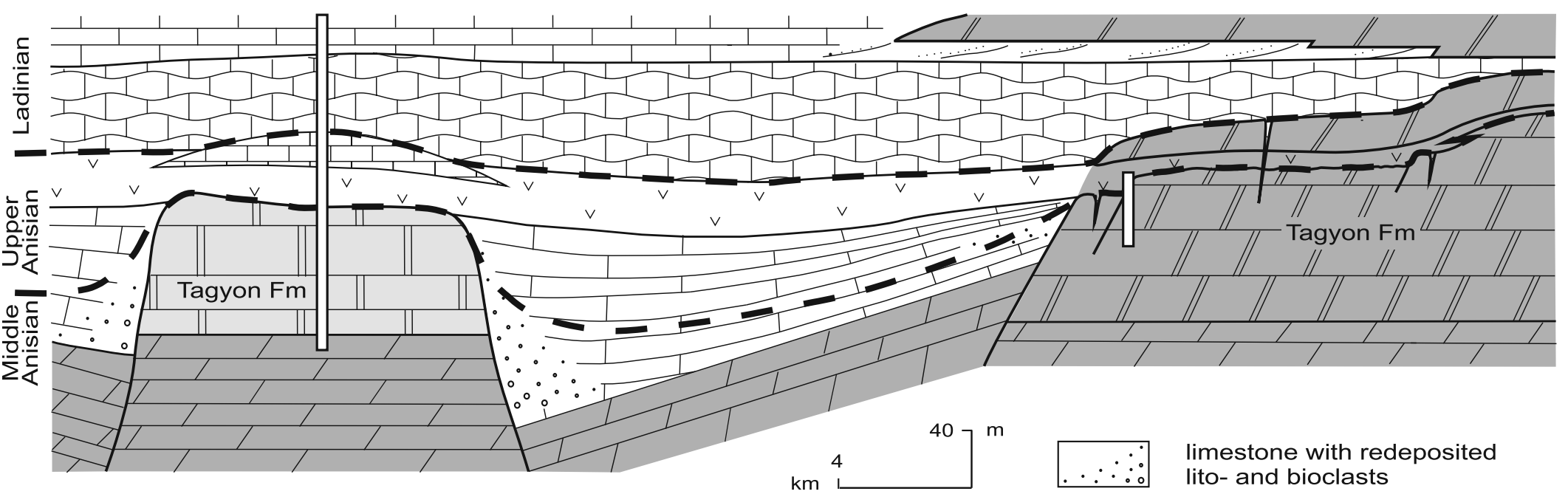

carbonates of ramp facies

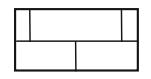

hemipelagic limestone

carbonate turbidite

carbonates of platform facies

pelagic limestone

partial dolomitization

volcaniclastics with

pelagic carbonate interbeds

neptunian dyke 


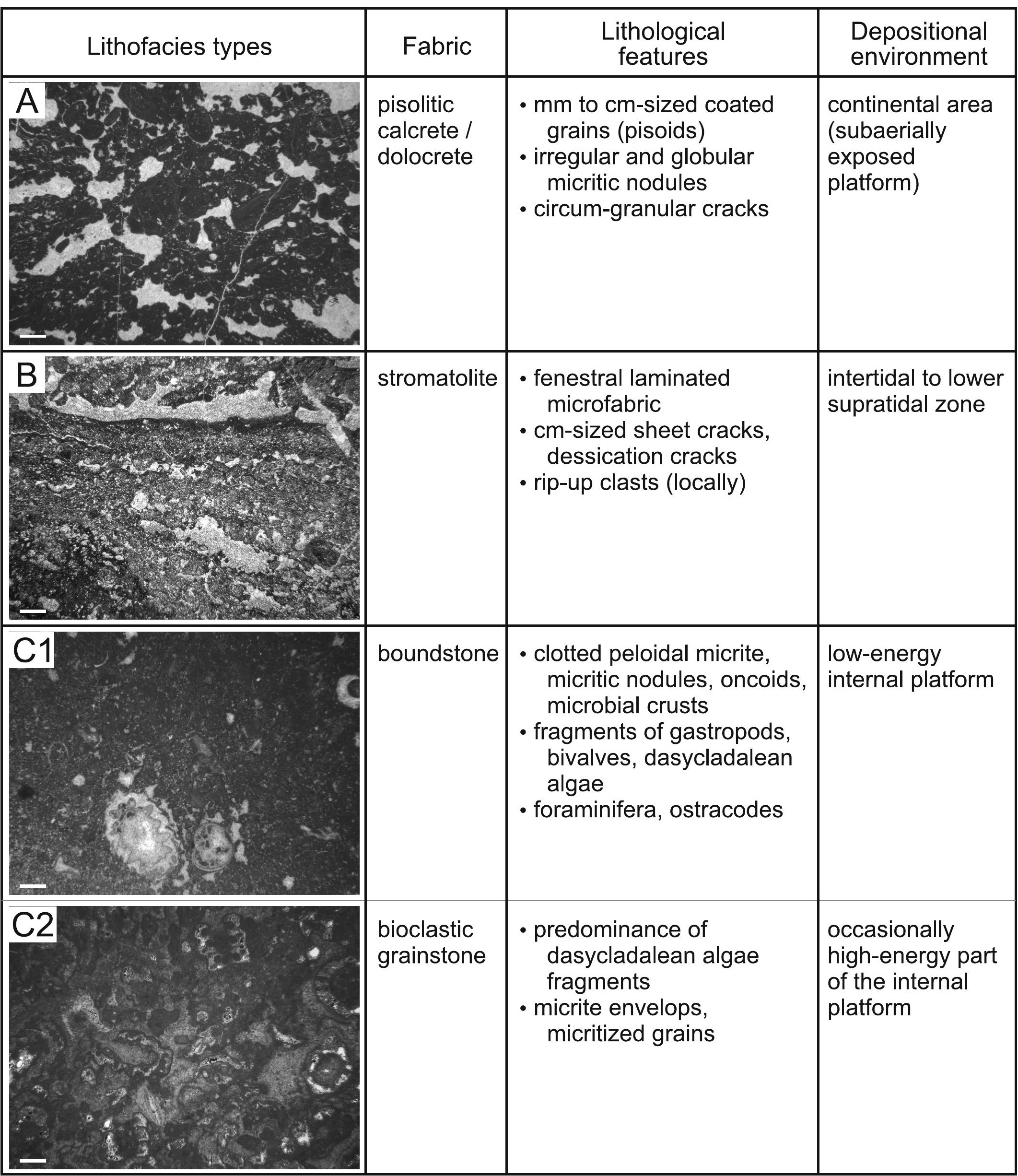









\section{a}

(25...

d

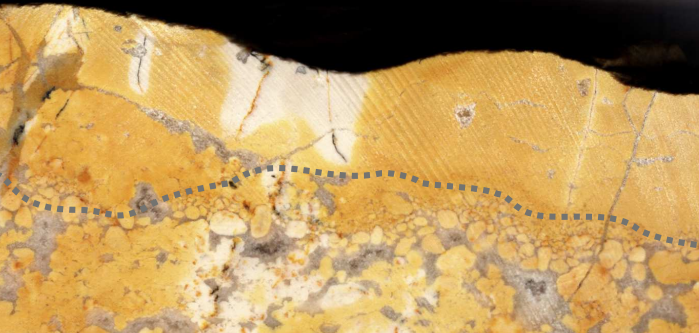
.
D

b

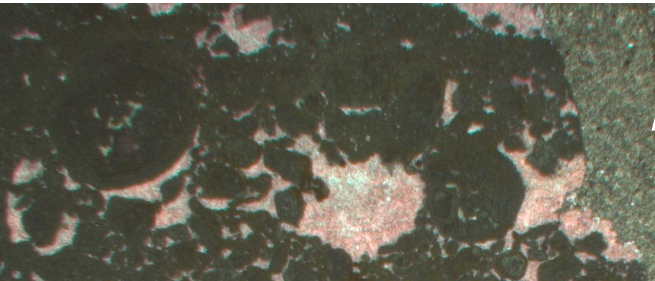

vfd

as

c

B

A

bc

bc

fd

fd
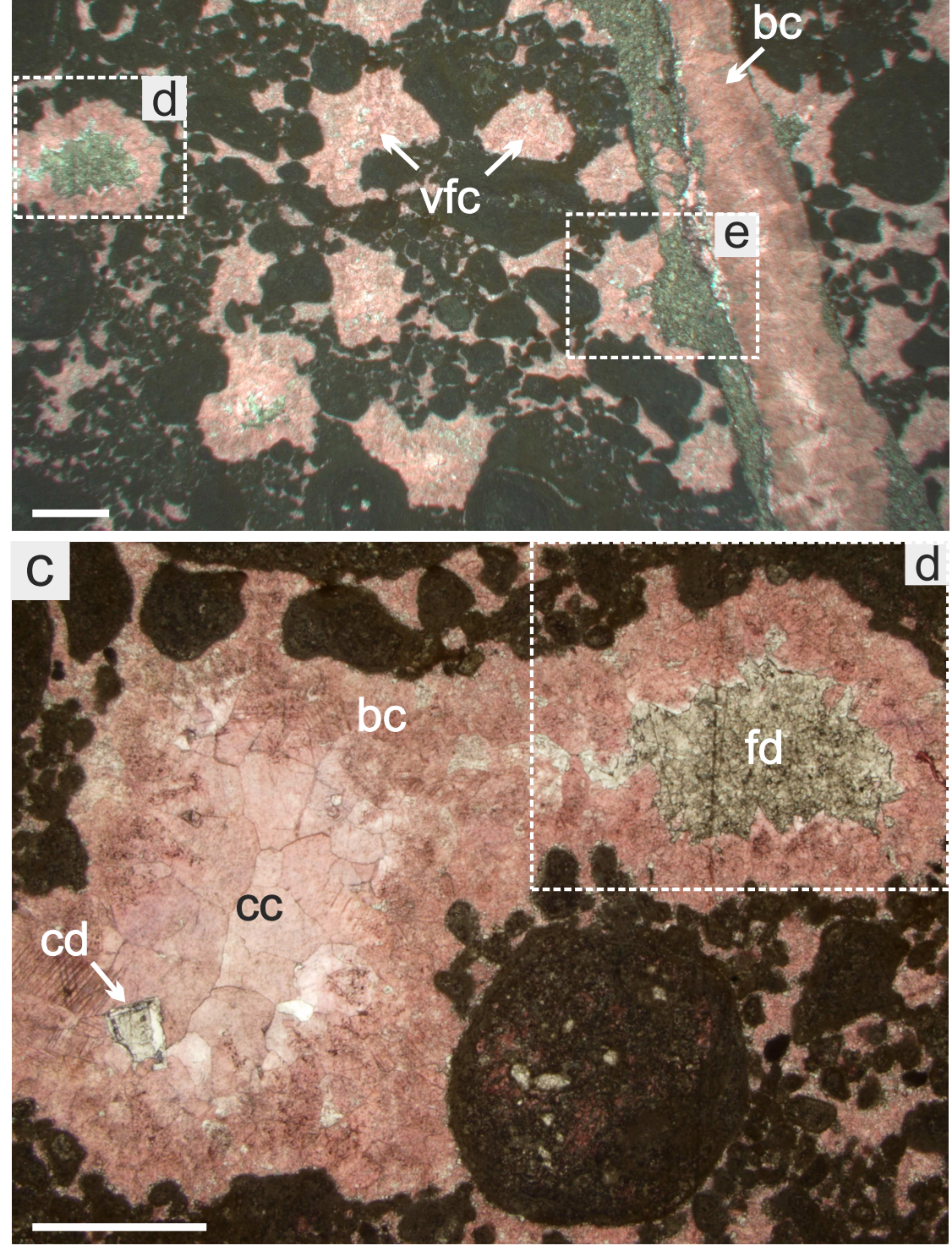

e fc 

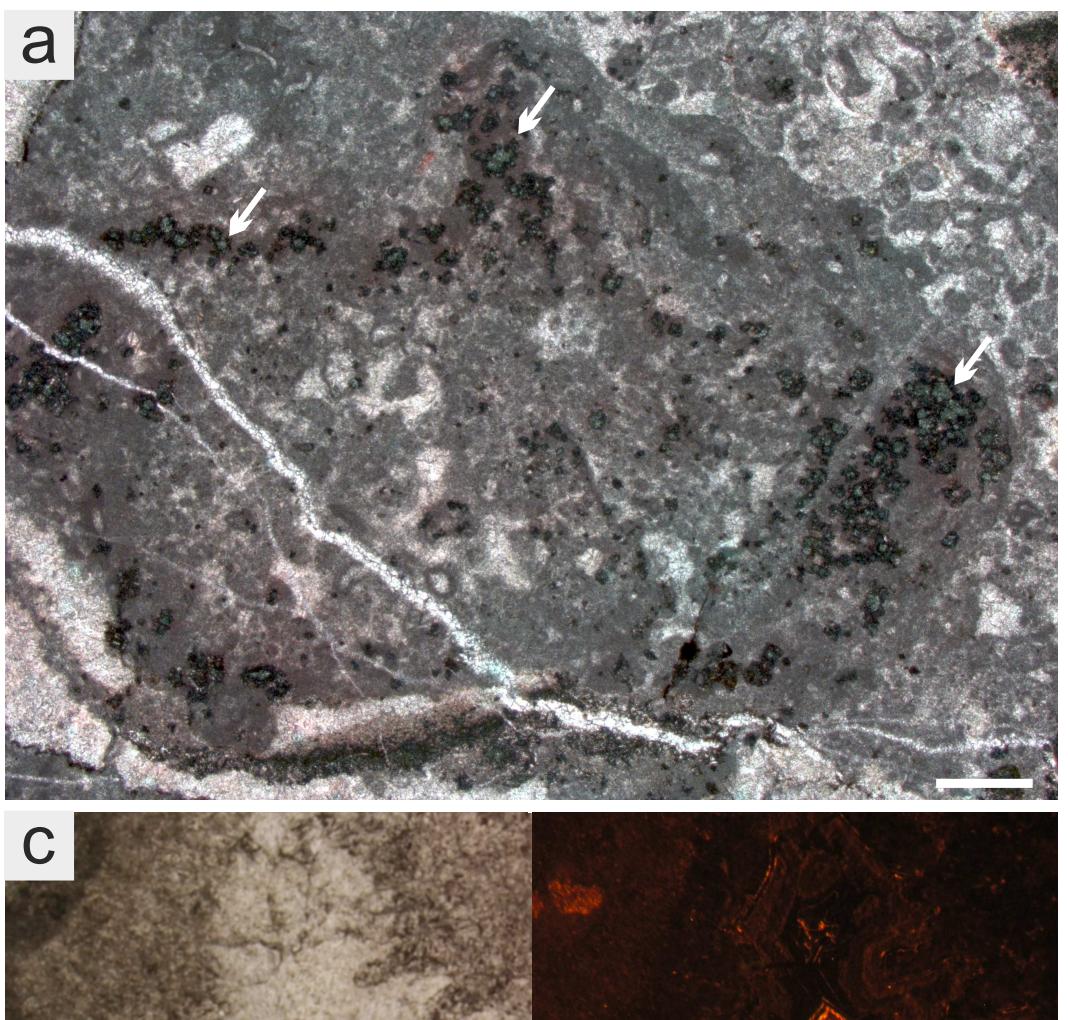

bc
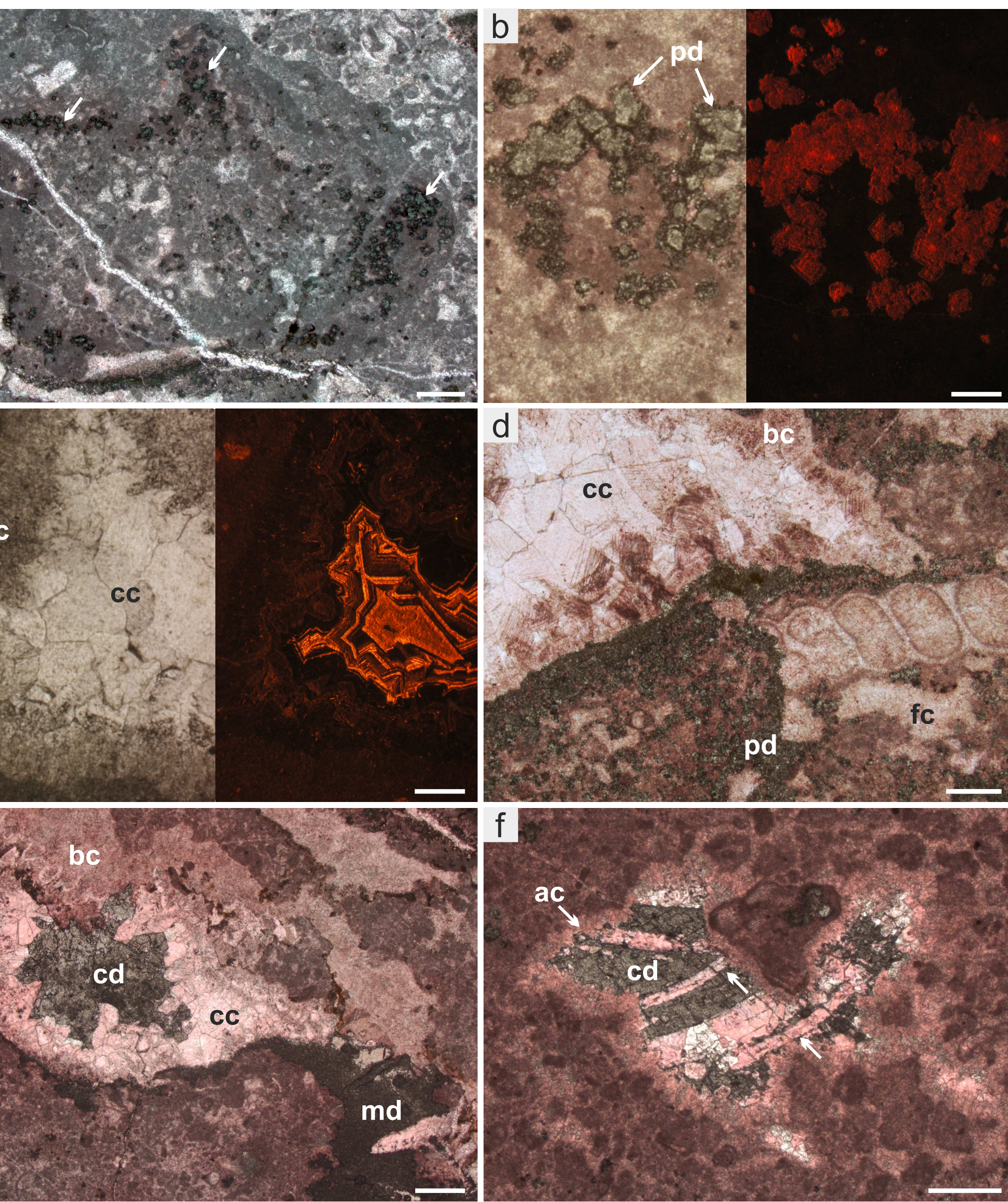

\section{e}

Ferabo

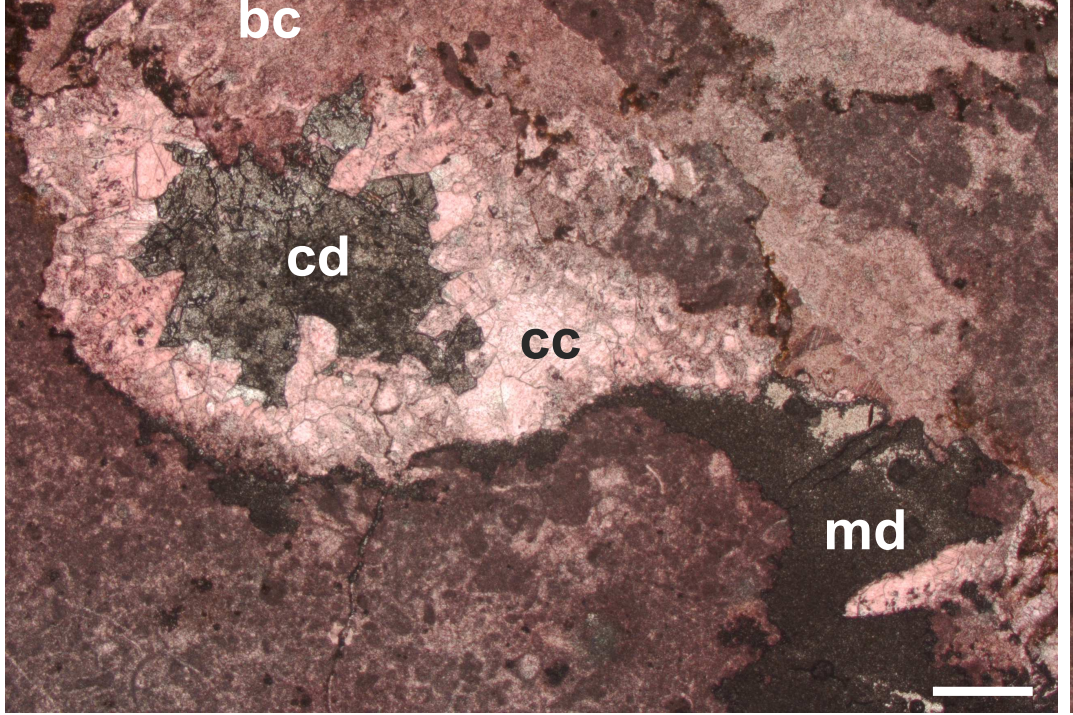


Figure 9
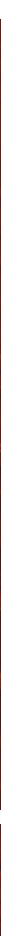

fd W. Det $x=0 d$ 13.

ats of

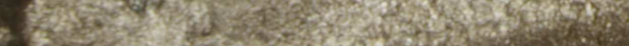

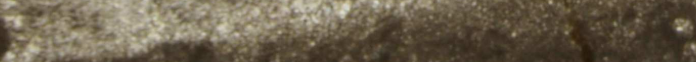




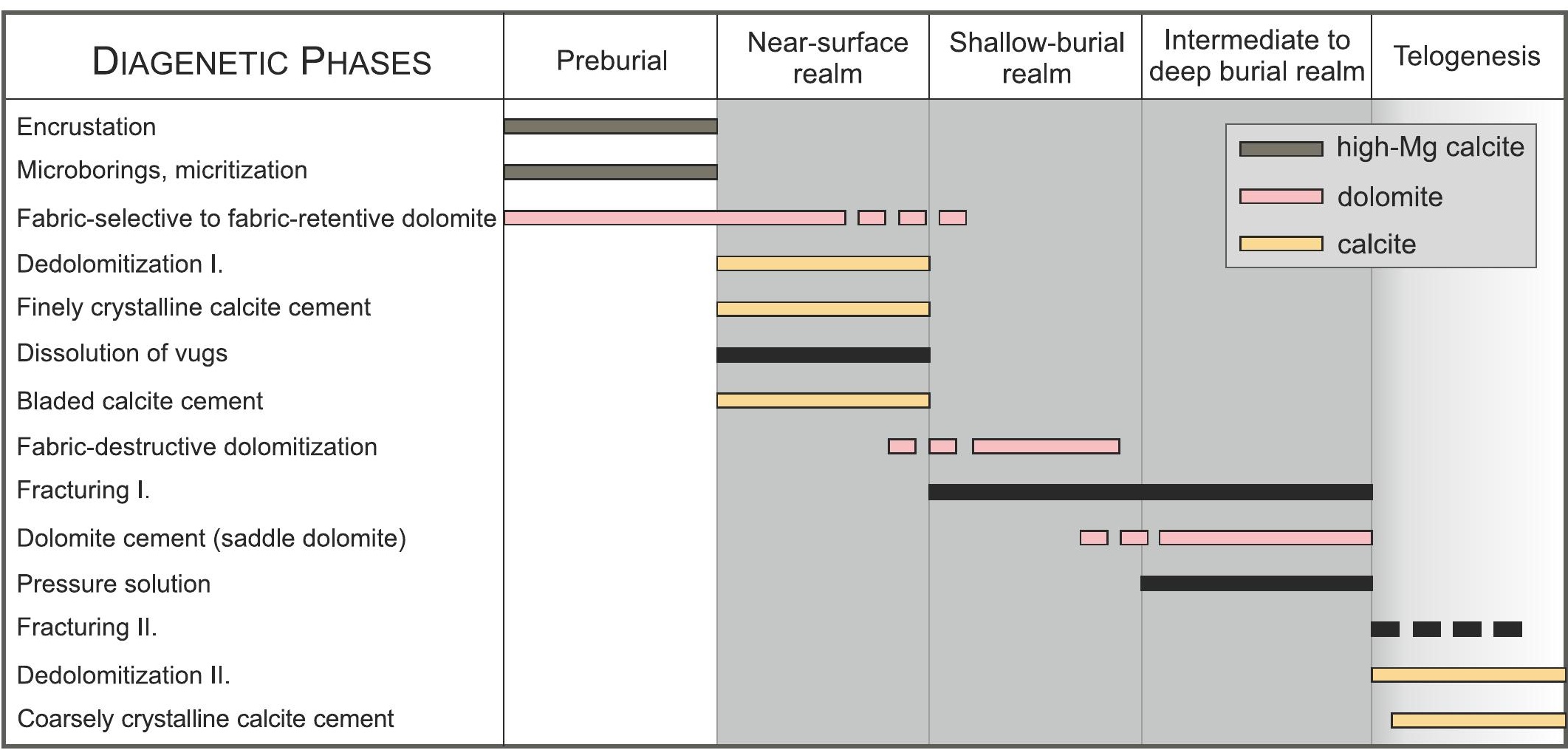



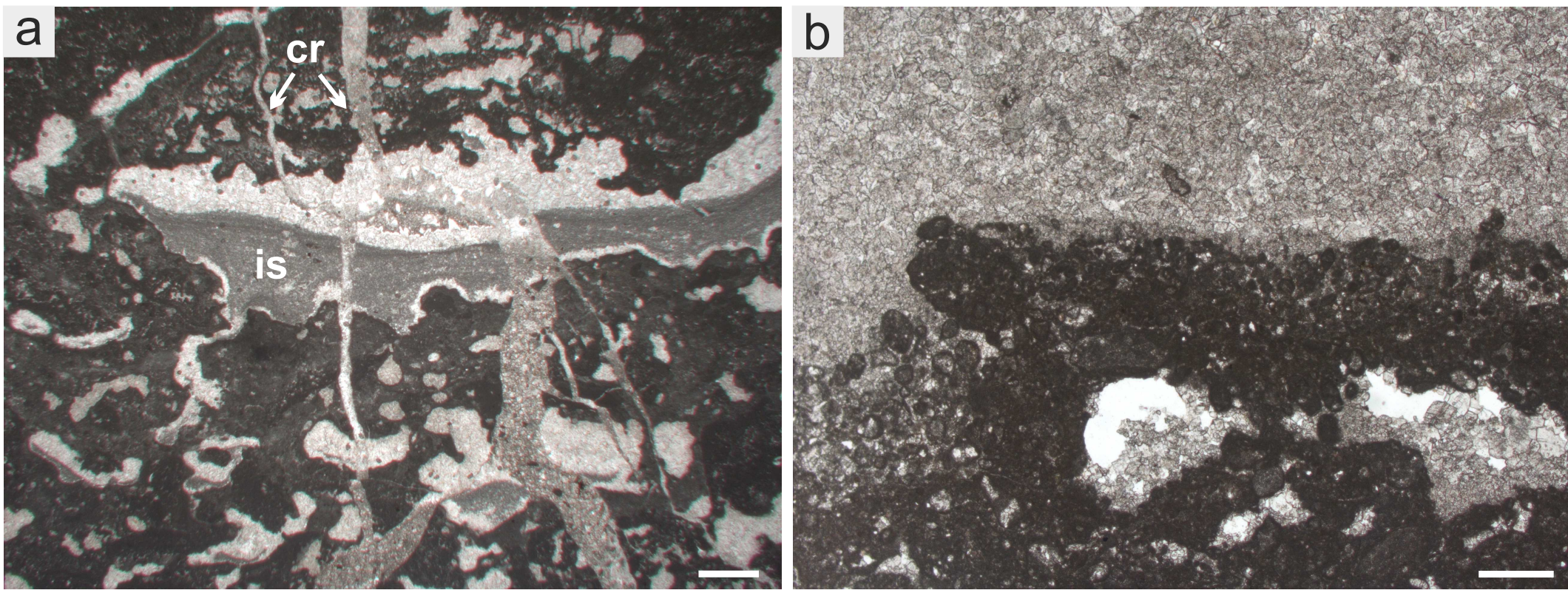

\section{C}
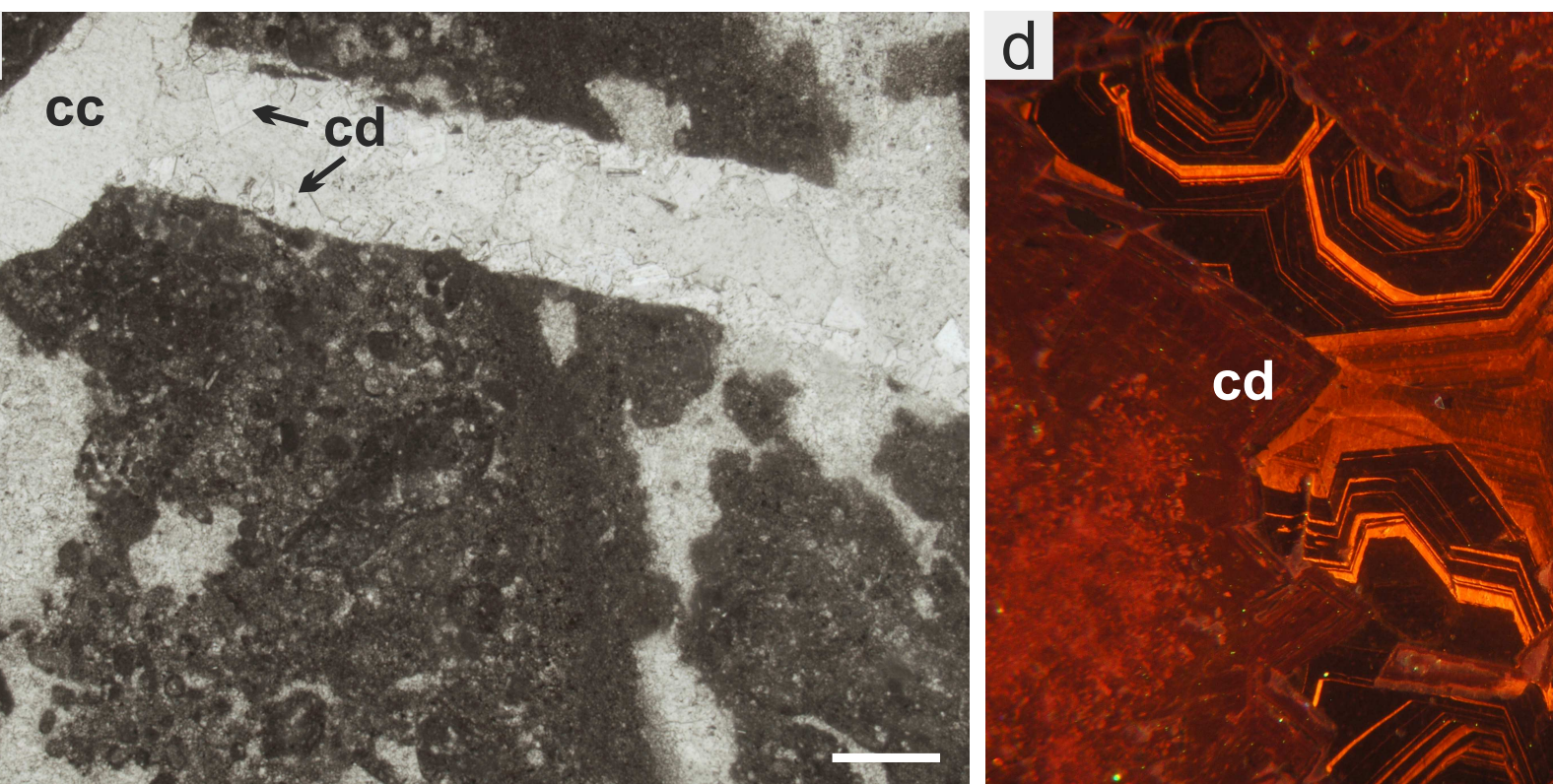

cd






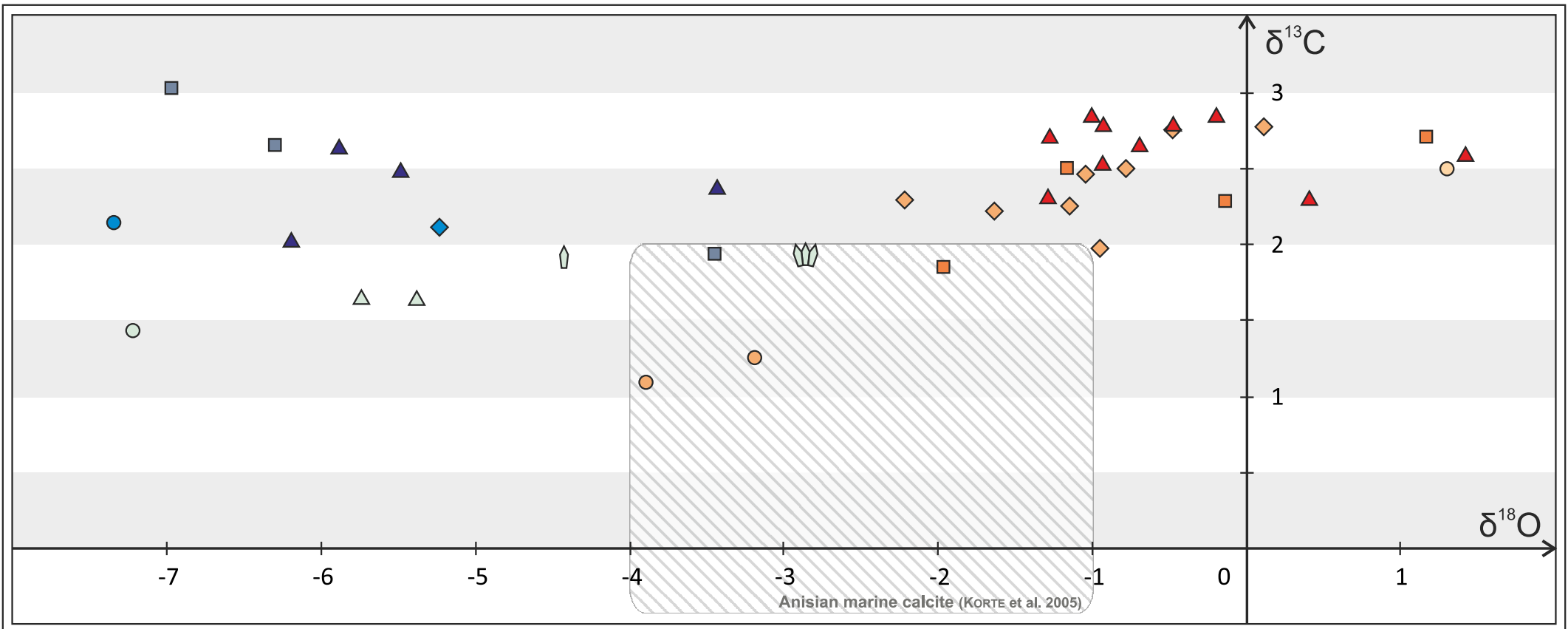

Szentkirályszabadja section

$\Delta$ fabric-retentive dolomite

$\checkmark$ fabric-destructive dolomite

$\diamond$ dolomite (replaced cement)

O dolomite cement

Core Drt-1

$\triangle$ calcite matrix

(M) radiaxial fibrous calcite cement

$\checkmark$ bladed calcite cement

O coarsely crystalline calcite cement
$\Delta$ fabric-retentive dolomite

- fabric-destructive dolomite

$\diamond$ dolomite (replaced cement)

o dolomite cement 


\begin{tabular}{|c|c|c|c|c|c|c|}
\hline & Sample & $\begin{array}{l}\text { Depth } \\
(\mathrm{m})\end{array}$ & Description & & $\begin{array}{c}\delta^{13} \mathrm{C} \\
(\mathrm{V}-\mathrm{PDB})\end{array}$ & $\begin{array}{c}\delta^{18} \mathrm{O} \\
(\mathrm{V}-\mathrm{PDB})\end{array}$ \\
\hline Szk & $129 \mathrm{C}-3$ & & nonplanar-a very finely crystalline dolomite, exhibiting fibrous appearance & dolomite (replaced cement)? & 2.78 & 0.10 \\
\hline Szk & $133-2$ & & medium crystalline, inclusion-rich, nonplanar-a dolomite, filling the pore among coated grains & dolomite (replaced cement) & 2.76 & -0.49 \\
\hline Szk & $133-3$ & & medium to coarsely crystalline, inclusion-rich, nonplanar-a dolomite filling the pore among coated grains & $\begin{array}{l}\text { dolomite (replaced cement) / } \\
\text { dolomite cement? }\end{array}$ & 2.28 & -2.22 \\
\hline Szk & 135A-B-1 & & fracture-filling medium to coarsely crystalline nonplanar-a dolomite & $\begin{array}{l}\text { dolomite (replaced cement) / } \\
\text { dolomite cement? }\end{array}$ & 2.26 & -1.16 \\
\hline Szk & 135B-1 & & vug-filling, finely to medium crystalline, nonplanar-a dolomite & dolomite (replaced cement) & 2.47 & -1.05 \\
\hline Szk & 135B-2 & & domal structure of planar-s to nonplanar-a very finely crystalline dolomite, exhibiting fibrous appearance & dolomite (replaced cement)? & 2.51 & -0.79 \\
\hline Szk & $135 \mathrm{C}-1$ & & nonplanar-a bladed dolomite filling a sheet crack & dolomite (replaced cement) & 2.23 & -1.64 \\
\hline Szk & $135 \mathrm{C}-2$ & & pore-filling bladed dolomite overgrown by coarsely crystalline saddle dolomite & $\begin{array}{l}\text { dolomite (replaced cement) + } \\
\text { dolomite cement }\end{array}$ & 1.98 & -0.96 \\
\hline Szk & $131 a$ & & vug-filling medium to coarsely crystalline saddle dolomite & dolomite cement & 1.10 & -3.90 \\
\hline Szk & $134 \mathrm{~A}$ & & vug-filling medium to coarsely crystalline nonplanar-a dolomite & dolomite cement & 1.26 & -3.20 \\
\hline Szk & 134B-3 & & vug-filling medium to coarsely crystalline dolomite & dolomite cement & 2.52 & 1.28 \\
\hline Szk & $129 \mathrm{~A}-2$ & & nonplanar-a very finely crystalline to finely crystalline dolomite, exhibiting fibrous appearance & fabric-retentive dolomite & 2.80 & -0.94 \\
\hline Szk & 129B-2 & & laminated planar-s to nonplanar-a, very finely crystalline to finely crystalline dolomite matrix & fabric-retentive dolomite & 2.86 & -0.20 \\
\hline Szk & 129B-3 & & clotted, nonplanar-a, very finely crystalline to finely crystalline dolomite & fabric-retentive dolomite & 2.86 & -1.01 \\
\hline Szk & 129C-2 & & nonplanar-a, very finely crystalline to finely crystalline dolomite, exhibiting fibrous appearance & fabric-retentive dolomite & 2.66 & -0.70 \\
\hline Szk & $133-1$ & & $\begin{array}{l}\text { concentrically laminated, planar-s to nonplanar-a, very finely crystalline to finely crystalline dolomite crust around a } \\
\text { nodule }\end{array}$ & fabric-retentive dolomite & 2.80 & -0.48 \\
\hline Szk & 134B-2 & & $\begin{array}{l}\text { dolomicrite to very finely crystalline dolomite nodule with } 50 \text { to } 300 \mu \mathrm{m} \text {-sized vugs filled by finely crystalline } \\
\text { nonplanar-a dolomite }\end{array}$ & fabric-retentive dolomite & 2.60 & 1.41 \\
\hline Szk & $135 A-B-2$ & & laminated, nonplanar-a, very finely crystalline to finely crystalline dolomite matrix & fabric-retentive dolomite & 2.32 & -1.30 \\
\hline Szk & 135B-3 & & vug-filling, nonplanar-a, finely crystalline dolomite, exhibiting fibrous appearance & fabric-retentive dolomite & 2.54 & -0.94 \\
\hline Szk & $136 \mathrm{~A}-1$ & & clotted, nodular, nonplanar-a, very finely crystalline to finely crystalline dolomite & fabric-retentive dolomite & 2.31 & 0.40 \\
\hline Szk & $132 \mathrm{~A}-1$ & & nonplanar-a, very finely crystalline to finely crystalline dolomite matrix with relic micritic fabric elements & fabric-destructive dolomite & 2.72 & 1.15 \\
\hline Szk & $135 \mathrm{C}-3$ & & laminated, nonplanar-a, very finely crystalline to finely crystalline dolomite & fabric-destructive dolomite & 1.86 & -1.97 \\
\hline Szk & 131-1 & & very finely crystalline dolomite, with finely crystalline nonplanar-a dolomite patches and relic micritic fabric elements & fabric-destructive dolomite & 2.51 & -1.17 \\
\hline Szk & 134B-1 & & dolomicrite to very finely crystalline dolomite matrix with medium-crystalline nonplanar-a dolomite in patches & fabric-destructive dolomite & 2.29 & -0.15 \\
\hline Drt-1 & $142-3$ & 77 & dark, nodule of dolomicrite to very finely crystalline dolomite, with 10 to $400 \mu \mathrm{m}$-sized vugs filled by calcite (<10\%) & fabric-retentive dolomite & 2.38 & -3.44 \\
\hline Drt-1 & $142-2$ & 77 & dark, nodule of dolomicrite to very finely crystalline dolomite, with 10 to $400 \mu \mathrm{m}$-sized vugs filled by calcite $(<10 \%)$ & fabric-retentive dolomite & 2.50 & -5.49 \\
\hline Drt-1 & $67-3$ & 110.2 & dolomicritic matrix with small fenestral pores filled with very finely crystalline dolomite & fabric-retentive dolomite & 2.65 & -5.89 \\
\hline
\end{tabular}




\begin{tabular}{|c|c|c|c|c|c|c|}
\hline Drt-1 & $65-2$ & 125.3 & dark, brownish pisoid of very finely crystalline dolomite with micropores filled by calcite microspar $(<5 \%)$ & fabric-retentive dolomite & 2.04 & -6.20 \\
\hline Drt-1 & $141-1$ & 82.2 & nonplanar-a, very finely crystalline to finely crystalline dolomite matrix & fabric-destructive dolomite & 3.03 & -6.97 \\
\hline Drt-1 & $67-2$ & 110.2 & planar-s to nonplanar-a, finely crystalline dolomite & $\begin{array}{l}\text { fabric-destructive dolomite } \\
\text { (with remnants of peloids) }\end{array}$ & 2.66 & -6.30 \\
\hline Drt-1 & $67-4$ & 110.2 & planar-s to nonplanar-a, very finely crystalline dolomite matrix & fabric-destructive dolomite & 1.95 & -3.48 \\
\hline Drt-1 & $65-4$ & 125.3 & fracture-filling planar-s to nonplanar-a very finely crystalline to finely crystalline dolomite & dolomite (replaced cement) & 2.12 & -5.24 \\
\hline Drt-1 & $63-2$ & 144 & medium to coarsely crystalline nonplanar-a dolomite filling fenestral pores & dolomite cement & 2.15 & -7.35 \\
\hline Drt-1 & $139-1$ & 101 & peloidal clotted micrite, very finely crystalline to finely crystalline calcite & calcite matrix & 1.65 & -5.39 \\
\hline Drt-1 & $66-2$ & 112.6 & $\begin{array}{l}\text { peloidal, nodular micrite, very finely crystalline to finely crystalline calcite (with less than } 2 \% \text { of porphyrotopic } \\
\text { dolomite) }\end{array}$ & calcite matrix & 1.66 & -5.74 \\
\hline Drt-1 & $142-1$ & 77 & mosaic calcite filling a vug below a nodule (with less than $5 \%$ dolomite inclusions) & calcite cement & 1.44 & -7.22 \\
\hline Drt-1 & $139-3$ & 101 & pore-filling radiaxial fibrous calcite & calcite cement & 1.94 & -2.87 \\
\hline Drt-1 & $65-3$ & 125.3 & fracture-filling bladed calcite & calcite cement & 1.92 & -4.43 \\
\hline
\end{tabular}

